\title{
The Good, the Bad and the Ugly of Tillage in Agricultural Sustainability- A Review
}

\author{
NWEKE I. A.
}

Department of Soil Science Chukwuemeka Odumegwu Ojukwu University, Anambra State.

\section{ARTICLE INFO}

Article No.:090618130

Type: Review

DOI: 10.15580/GJAS.2018.9.090618130

Submitted: 06/09/2018

Accepted: 11/09/2018

Published: 29/09/2018

*Corresponding Author

Nweke I. A.

E-mail: nweksoniyke@gmail.com

\section{Keywords:}

Aggregation, crop yield, soil

characteristics, soil strength, tillage,

water infiltration
Soil is the most precious gift of God to mankind and its proper management is a key to sustainable crop production and other life existence on this planet earth. In arable crops production soil tillage is usually noted for having greatest requirement for energy and labour consumption. Thus one of the important soil management is the proper amount and type of tillage system in use by the farmer, because the potential for erosion either by water or wind of a specific soil type depends largely on the number and types of tillage operations. Any method adopted must ensure the long - term productivity of soil, environmentally friendly and profitable. Tillage operations improve chemical, biochemical, biological, physical and hydro-physical properties of soils and these consequently increase soil water conservation and yield of crops. Surface sealing and roughness, crusting, hardpan and soil compaction reduce drastically with proper tillage operations of which will increase soil water storage and availability to crops. This paper reviewed various terms used for soil tillage its potentials and draw back in agricultural sustainability. 


\section{INTRODUCTION}

Tillage has been an integral component of crop production system since the beginning of agriculture. Soil structural modification through tillage is aimed at optimizing soil conditions for seed germination, seedling mergence and crop growth. In general any good tillage system should provide good soil tilth, improve soil water infiltration and retention, reduce weed competition, minimize soil erosion, control infestation of pests, encourage biological activities of soil micro-organisms and recycle soil organic matter through residue management. Tillage practices are known to influence soil physical condition, nutrient availability, growth and yield of crop. The principal aim of all mechanical applications on soil is to cultivate soil for sowing seeds, though they may have other functions as well, are in the scope of soil tillage. Depending on the soil tillage practice, it is known that soil depth, level of OM and differences in pore system may all be pressure elements on plant growth. Besides this, different soil tillage methods can affect soil's behaviour against factors of erosion. Therefore, soil tillage techniques have a significant impact onsustainable soil management. The influence of tillage on soil physical, chemical and biological properties according to Ishaq et al. (2002) are a function of soil properties, the type and intensity of the tillage systems and environmental conditions. They further stated that the contradictory results of tillage effects on soil properties found in the literature may be due to differences in some of the followings; crop species, soil properties, climatic characteristics and their complex interactions. Therefore, they hypothesized that it will be necessary to examine the long-term effects of tillage at different locations and under various environmental and soil conditions so that more accurate generalizations can be made regarding the conditions required for sustainable tillage systems.

Thus the following authors Adamu and Abdulrazaq (2004); Aluko and Lasisi (2009) and Agbede (2010) asserted that in many ecological zones and on different soil types, crop response to tillage and indeed the economic viability of tillage systems is still subject of investigation. Tillage is defined as the soil related actions necessary for crop production and according to Antapa and Angen (1990), tillage is any operation or practice taken to prepare the soil surface for the purpose of crop production. The definition by Ahn and Hintze (1990) sates that tillage is any physical loosening of the soil as carried out in a range of cultivation operations, either by hand or mechanized, the overall goal of production while conserving resources (soil and water) and protecting the environment. Am-Eurason (2009) in his owns study see tillage as physical, chemical or biological soil manipulation to optimize conditions for seed germination, seedling establishment and crop growth. Brady and Weil (1999) in their own work defined tillage as the mechanical manipulation of soil for any purpose but in agriculture it is usually restricted to modifying of soil conditions for crop production. Prihar et al. (2000) opined that tillage is the physical manipulation of soil performed to create condition suitable for germination of seeds, seedling emergence and growth to reduce competition from weeds. CTIC (2004) found tillage as all practices geared towards seed bed preparation that optimize soil environmental conditions for seed germination, seedling establishment and crop growth. The benefits of tillage therefore include among other things, seed bed preparation, weed control, evaporation suppression, and water infiltration enhancement and erosion control. There are various type of tillage; conventional tillage (CT) involves full weight tillage which disturbs the entire soil surface, It generally involves ploughing and numerous tillage trips on the field; conservation tillage this type of tillage involve planting in the previous crop residues that are purposely left on the soil surface (CTIC 2004). There are also various methods of conservation tillage which are No-till/zerotillage/flat, defined as a method of planting crops into untilled soil by opening narrow slot or trench only of sufficient width and depth to obtain proper seed coverage; minimum tillage is another conservation tillage method that minimizes soil disturbance and allow residue remain on the ground instead of being incorporated into the soil, mound and ridge popular tillage methods in tropical countries like Nigeria belong to this type only that the residues do not remain on the ground during tillage action; reduced tillage is conservation tillage that does not involve soil inversion but maintain a high level of surface residue. This review therefore intended to report on various impacts of tillage on soil, crop growth and yield and agricultural sustainability.

\section{Effect of different tillage methods on soilphysical properties}

Tillage has been part and parcel of crop production system since the beginning of agriculture. The new approaches to tillage operations, compared with the conventional ploughing systems tend to reduce the number of tillage operation or amount of diesel that is used, the amount of dust that is generated (Reicosky 2002). The non-judicious tillage practices by the farmers can result in various soil problems. For example in Asia the use of inadequate tillage methods by the farmers have caused many soil problems in the area (Lal, 1990). Further due to certain challenges faced by farmers in the use of conventional tillage method such as high gasoline consumption, compaction of soil and structure degradation, Mithell (2009) opined that this has resulted in the use of alternative method with zero tolerance to erosion.

Minimum or reduced tillage is when a residue of $15-30 \%$ is left in to cover the soil after planting, any of the method due to limited soil disturbance is capable of reducing the chances of erosion and crusting of soil (Lal 1997, 1999; Belvins and Frye 1993; ECAF 2004). Tillage 
methods have various influence on the physical characteristics of soils both beneficial and degrading depending on the appropriateness and method used (Kladivko 1993). Conservation tillage influence physicochemical properties of soils greatly because of much crop wastes left on the soil surface. Tillage methods affect physical characteristics of soils such as aggregate size distribution, $\mathrm{H}_{2} \mathrm{O}$ content, BD, TP, penetration resistance, soil temperature etc. Fabrizzi et al. (2005) using NT method found out that the impact of tillage on soil physical characteristics were very much dependent on the intensity of the tillage method, land use history, climate (geographical location) conditions and differences in soil parameters. Osunbitan et al. (2005) worked on the influence of tillage method on HC, strength and bulk density of a loamy sandy soil. Their findings showed that increasing the intensity of tillage exercise decreased the penetration resistance and BD of the soil. The conventional tillage method results in increased soil erosion due to break down in physical characteristics of soil.

Tillage impacts on the changes of soil characteristics have been noted by Chang and Lind wall (1990) to be an index of soil type, state of climate, implements in use, moisture content at the time of tillage and depth of tillage. Higher content of undecomposed crop wastes at the surface of soil cause slaking which is good as it ensures strong structural stability of soil particles. When slaking is reduced through plough less tillage Rydberg (1990) observed that the rate of evaporation is reduced though higher in silt clay loam compared to heavy clay an indication that type of soil also affects the result obtained.

\section{DEFINITION AND TYPES OF TILLAGE}

Tillage is defined by CTIC (2004) as all practices done on soil to ensure an ideal seedbed environment for easy germination of seed, growth and development.

\section{TYPES OF TILLAGE SYSTEM}

The various types of tillage are;

\section{CONVENTIONAL TILLAGE}

This type of tillage involves full width tillage which disturbs the entire soil surface. It generally involves ploughing and numerous tillage trips (CTIC 2004).

\section{CONSERVATION TILLAGE}

This type of tillage involves planting in the previous crop wastes that are purposely left on the surface of the soil (CTIC 2004).

\section{METHODS OF CONSERVATION TILLAGE}

i. No-till/zero-tillage:
This method involves creating small opening sufficient in depth and width for planting of seed and proper seed coverage.

ii Minimum tillage:

Conservation tillage method is when plant residues are allowed on the surface of soil instead of being worked into the soil with minimal soil disturbance.

iii. Reduced tillage:

Reduced (conservation) tillage is a method that does not involve soil inversion but maintain a high level of surface residue.

Soil tillage practices plus use of manure are preliminary actions in crop production. These actions affect conditions such as soil physical conditions, availability of nutrient, crop growth and yield. Tillage methods significantly affect soil physical characteristics as they increased soil water content, decreased soil penetration resistance among different tillage (Hemmat and Taki 2001). In an experiment designed by Sarauskis and Romaneckas (2002) in Lithuanian University of Agriculture where they compared direct drilling and sowing of sugar beet in cultivated and ploughed soils, their findings showed insignificant in quality parameters and yield and that soil water was $4.4-5.6 \%$ in loam than in ploughed and cultivated soil at seed placement depth. Germanas and Bakasenas (2004) and Lukosiunas (2005), observed yield decline in barely and winter wheat, in unremoved straw and seeds directly drilled into unloosed stubble.

Excessive pulverization of soil by conventional tillage practice as reported by Temesgen (2007) results to poor soil structure and crust formation. An important agricultural activity like soil tillage creates much impact on soil characteristics (Chivenge et al., 2007; Lal 2009; Chatterjee and Lal 2009). Strudeley et al. (2008) showed that no constant trends were observed when they studied effect of different tillage techniques on soil physical attributes. However the effects of No-tillage on soil physical attributes were found to be improved (Lal 1997; Strudley et al., 2008; Alvarez and Steinback 2009), while Temesgen (2007) recommended in tropical soils an appropriate tillage practices for the implement of soil hydraulic properties. Generally, tillage influences are more effective in poor soils and harsh environment compared to fertile soils of cool macro and mesoclimates (Aboudare et al., 2006; Lal 2009). Ethiopian famers make use of traditional tillage method called meresha commonly directed by oxen (Aure et al., 2001; Gebrezhler et al., 2006). Due to pulverization of the vshaped drafted meresha it causes poor structure and rust formation (Temesgen, 2007).

The improvement of soil architecture by tillage is aimed at modifying soil environment to easy seed germination, establishment and development. Above all adequate soil tilth through tillage is aimed at treating OM 
through agricultural wastes management of which activates the activities of soil organisms, reduce soil erosion, control pest and weed infestation and encourage the rate of water entering the soil and retention capacity. In view of this tillage methodsin many typesof soil and characteristics, response of crop, economic feasibility in many geographical location has made the operation a continuous discuss (Adamu and Abdulrazaq, 2004; Aluko and Lasisi 2009; Agbede 2010). Researchers in savannah and forest zones of Nigeria have shown that NT performed below expected (Ojeniyi 1997; Adamu and Ezeaku 2002). Tillage practices influenced physical conditions of soil and yield of crops (Rashidi and Keshavarzpour 2008; Keshavarpour and Rashidi 2008). Lal (1993) reported that when tillage operations are properly done it enhance soil related constraints, while inadequate tillage practices cause soil structure deterioration, plant nutrients and organic matter depletion, increases the incidence of erosion, disrupts soil organic carbon and water cycles. This is harmful to soil in the use of much and unwarranted tillage operations. Presently as noted by lqbal et al. (2005) for soil erosion control farmers' interest have tended towards NT and conservation tillage.

The principal aim in all mechanical applications on soil is to create an ideal environment for seed sowing in line with other functions as well, are being achieved by soil tillage. Depending on the tillage practice in use pressure on crop growth can evolve from pore size system, depth of tillage and range of OM. Apart from this, tillage systems against causes of erosion influenced all processes in soil. Thus tillage techniques have an important impact on soil sustainability. Reports from various researches on the impact of tillage methods on soil surface roughness, penetration resistance, aggregation, bulk density (BD), seed germination and crop yields have been reported (Dao 1993; Hermawan and Bomke 1997; Do-an et al., 2000; Guzha 2004; Ozpinar and I-ik 2004; Cetin et al., 2005; Ozpinar and Cay 2005; Licht and Al-Kaisi 2005; I_ildar and Bayhan 2005). Hence appropriate tillage system as an option is a panacea to water retention for the benefit of crops in dry land agriculture with increased water infiltration and decreased surface flow.

The effect of tillage on soil characteristics according to Ishaq et al. (2002) is dependent on soil characteristics, the type and intensity of the tillage systems and environmental conditions. They further stated that soil characteristics, crop types, climate conditions and their interactions cause the differences observed in the effect of tillage practices or soil properties. Therefore, they hypothesized that it will be worthy to assess the impact of long-term tillage at different geographical zones, soil types and weather conditions with this consensus with regards to sustainability of tillage methods by researchers can be achieved.

\section{Effect of Tillage Methods on Soil Chemical Properties}

Land use management systems assess soil organic matter (SOM) just as intensive soil properties or environmental factors. Conventional tillage (CT) has being noted by Christensen (1996) to cause decrease in organic carbon contained in soils causing higher degradation and OC redistribution in soils. After 9 year studies, Franzluebbers et al. (1994) in southern part of USA observed soil organic carbon to be higher in sole wheat by $9 \%, 22 \%$ higher in wheat rotated with sorghum and $39 \%$ higher in wheat/soybean compared with conventional tillage. They argued that intensive cropping is responsible for higher accumulation of soil organic carbon in NT compared with conventional tillage. In crop production zones however, similar results have equally been reported. In a tropical Oxisol, Balota et al. (2004) reported $45 \%, 34 \%$ and $14 \%$ increase in soil organic carbon in $0-50 \mathrm{~mm} ; 50-100 \mathrm{~mm}$ and $200 \mathrm{~mm}$ depth with NT compared with conventional tillage. In Nebraska, Six et al. (1998) conducted on Mollisol a 25 years tillage research and they found out that in $0-5 \mathrm{~cm}, \mathrm{ON}$ and $\mathrm{OC}$ were significantly higher in NT over CT, but the result was not the same with $5-20 \mathrm{~cm}$ depth, short term studies showed no difference in soil organic carbon with 5-years time/span of the study (Bergstrom et al., 1998).

In long term studies with NT practice, soil organic carbon was found to increase; reason being that soil organic takes time to accumulate in NT but $\mathrm{N}$ appears to change fast (Six et al., 1998). Bahaltacharyya et al. (2008) in 18 years study observed higher concentration of $\mathrm{OC}$ in reduced tillage and no-tillage systems over conventional tillage system. Melero et al. (2008) in their studies attributed non significant tillage effect of organic carbon in $10-20 \mathrm{~cm}$ and $20-30 \mathrm{~cm}$ depth to high content of clay in the soil studied.

Gregorich et al. (1994) stressed that soil structure and micro-aggregates degradation caused by relatively often and deep plough system cause loss of $\mathrm{OC}$ in CT and that soil OM is an index of soil quality. For biological, chemical, and physical qualities of the soil, Bradford and Peterson (2000) advised that SOM need to be increased.

Dalal (1992), reported higher content of NT in no-tillage over conventional, while Heenan et al. (2004) observed increased TN content of the soil in NT and reduced tillage method over CT. Madejon et al. (2007) and Green et al. (2007) attributed the effect of tillage systems on the total organic carbon and total nitrogen to decrease in the total organic carbon and total nitrogen concentration contained in the soils. McCarty et al. (1998) observed that tillage methods showed small or no differences in total $\mathrm{N}$ content retained in $1^{\text {st }}$ year of application, and Aon et al. (2001) reported significant differences only after 3 years of practice. The studies of Roldon et al. (2005), on no tillage and reduced tillage reported that decreases are not only in the delay of dehydrogenase activity but also in TON and TN. For many soil researches, it has being observed that 
dehydrogenase activity and TON has significant positive correlation (Bastida et al., 2006; Truu et al., 2008; Melero et al., 2008). Strudley et al. (2008) argued that the intensity of tillage and depth affect chemical parameters of soil of which invariably influence crop growth and yield.

Nonetheless, deep tillage practice according to findings of Diaz-Zorita (2000) and Strudley et al. (2008) allows for deeper placement of fertilizer, improved aeration, drainage, $\mathrm{H}_{2} \mathrm{O}$ infiltration in soil, increased root depth, development and proliferation. Buah and Mwinkaara (2009) reported the impact of nitrogencomposed fertilizer on the organic content of the soil as to promote seed germination and plant development. In five years studies, Gomez et al. (2001) observed that the time span was enough to record significant changes in soil parameters. While Bessam and Marbet (2003) opined that CT influences soil aeration, OM breakdown and soil nutrients that support crop growth. Tillage systems according to Alvaret et al. (1995) enhance oxygen concentration in the soil thereby increasing $\mathrm{OM}$ mineralization and release of $\mathrm{CO}_{2}$ into the atmosphere. Nitrogen seems to be the most abundant in oxidation of nutrients contained in the OM. Shah et al. (2009) therefore argued that these plant nutrients released and picked up by plants are good values provided by tillage systems but last for short period. Carbon does not have a known value but soil nutrients do, hence soil organic carbon is given up to increase plant nutrients available to crops only for a short time. This economic benefit to the crop farmer is only but for a short period, but in a longer time cause degradation of soil structural properties, $\mathrm{H}_{2} \mathrm{O}$ and air.

No-till limits the rate of SOM losses thus improves soil carbon and nitrogen contents (Bayer et al., 2001). Zero-till reduces soil compaction due to the number of passes of tillage machines over the land are reduced. The food and agricultural organization conservation agriculture website now include as part of conservation agriculture; field traffics following permanent tracks. Sayre and Hobbs (2004) observed that it cannot be achieved by planting on the flat but by using a ridge-till method. Franzluebbers et al. (1995a) was of the opinion that $\mathrm{CO}_{2}$ emissions that may continue in a long-term conventional method may not have been accorded adequate consideration. According to Alvarze et al. (1995) Conventional systems is among the series of agricultural activities that contribute in the transmission of $\mathrm{CO}_{2}$ of between $0-1990 \mathrm{kgha}^{-1} \mathrm{C}$ within weeks of tillage.

Soil organic matter mineralizations liberates nitrogen and enhance crop yields over the short period, it causes mineralization of some plant nutrient elements and their losses through water into deeper layer of soil. This scenario is very important in tropical regions where OM decline is much observed with low rates of SOC after 10 or 20 years of conventional practice. Soil organic matter loss is minimized by zero-tillage and one of the means of increasing soil $\mathrm{N}$ and $\mathrm{OC}$ contents (Bayer et al., 2001).Soil organic matter is important to soil organisms of which earthworm is an example, this organism enhance ecosystem and agricultural stability (Birkas et al., 2004), it creates channels in soil thus improves soil aeration and water infiltration as well as nutrient recycling and availability (Lavelle et al., 2006). According to Desjardins et al. (2003), worms encourage the formation and stability of macro-aggregates; stimulate the activities of micro-organisms by enhancing the OM degradation. The population of these worms according to Caner et al. (2006) and Chan (2001) however are been influenced by conservation tillage practices and the quantity of crop residues. In some soils, the worms can create channels of depth 20-200 $\mathrm{cm}$ or even more through this nutrients, air and water circulation, roots proliferation in soil are enhanced. Conventional tillage as reported by Andren et al. (2001) and Brown et al. (2000) to cause degradation of soil structural stability, compaction, high water loss and reduction in earthworm population. This eventually results in low nutrient availability for plants uptake

Cambardella and Elliott (1992) after examining tillage treatments in a loam soil of north east Sidney, 2 decades to a depth of $20 \mathrm{~cm}$; reported that particulate organic matter (POM) under no-till was 36\% compared with conventional tillage. They argued that even in stubble mulch the degradation of POM was more rapid in conventional tillage compared to no-till as crop production inputs are not different between the tillage practices. Above all, the type of fresh crop wastes command high $\mathrm{C} / \mathrm{N}$ ratio as against much degraded crop wastes. For highly degraded plant wastes materials, the ratio is $10: 1$ and ratio decrease with the rate of decomposition. In view of this, the slower the degradation of the waste materials, especially at early stage of the degradation implies higher $\mathrm{C} / \mathrm{N}$ ratio. However, Franzluebbers and Arshad (1997) significantly observed that in four different locations in British Columbia and northern Alberta, the top soil of $0-5 \mathrm{~cm}$ show higher $\mathrm{C} / \mathrm{N}$ ratio. When the $\mathrm{C} / \mathrm{N}$ ration of particulate organic matter averaged to $200 \mathrm{~mm}$ depth non-significant differences was observed by the authors. Although Cambardella and Elliot (1992) observed significant differences of which they attributed to weather conditions, soil temperature and water and that the availability of wastes materials can affect particulate organic matter degradation in between the tillage treatment.

Tillage treatments as well change hydrolysable and mineralizable soil organic matter pools. Franzluebbers et al. (1994) working on top soil with aerobic incubation at $25^{\circ} \mathrm{C}$ for 3 weeks and 3 days found out that mineralizable carbon in no-till was significantly higher than that of conventional tillage in all cropping systems studied. Minor changes in particulate organic matter or soil microbial biomass are always identified with mineralizable carbon the reason being that slow and passive carbon pools contribute little to short period incubation relative to mineralzable carbon. The estimates of mineralizable nitrogen are usually very complex and much variable due to relatively low content 
of $\mathrm{N}$ and $\mathrm{N}$ re-immobilization. Researches on the influence of tillage treatments on soil hydrolysable carbon (SHC) are very small as against other labile carbon pools. The reason may be using strong acid at high temperature after 18 hours of digestion $C$ pool are all labile $\mathrm{C}$ pools and some of slow $\mathrm{C}$ pools. The second reason is complex procedures and specific machine used. When the labile carbon pools are compared with the passive and slow $\mathrm{C}$ pools, cultivation have less effect on slow and passive $C$ pools hence more stable than labile pools. Tillage practices still affect mineral containing carbon although it is assumed a protected pool. Mineral associated $C$ was found by Cambardella and Elliott (1992) to be $2566 \mathrm{~g} \mathrm{~m}^{-2}$ in native sod, no-till $2803 \mathrm{~g} \mathrm{~m}^{-2}$, in stubble mulch $2813 \mathrm{~g} \mathrm{~m}^{-2}$ and $2492 \mathrm{~g} \mathrm{~m}^{-2}$ for bare fallow respectively. Thus conventional tillage brought down significantly the size of slow $\mathrm{C}$ pool. The implication being that, more $\mathrm{C}$ was stored in no-tillage in this fraction compared with native sod, assumed to be in equilibrium for $\mathrm{C}$ dynamics. The degradation of particulate organic matter content in soils of grassland when originally ploughed and its further movement into slow carbon pool was suggested by the studies of these authors to have been the cause of the enrichment in mineral-associated $\mathrm{C}$.

Rovira and Vallejo (2002) defined resistant organic $\mathrm{C}$ as un-hydrolysable $\mathrm{C}$ after acid hydrolysis for 18 hours. This carbon pool turnover rate is very slower when compared with some other carbon pools. The turn over time of this resistant $C$ pool from the result of $14 \mathrm{C}$ dating conducted by Paul et al. (1997) on the average were over 1000 years of which increased with depth. Nonetheless, cultivation is still affecting carbon quantity. Collins et al. (2000) worked on 9 soils under long term studies in Corn Belt of east central of USA and found out that at $0-5 \mathrm{~cm}$ top soil no-till show significantly higher ROC over conventional tillage. They equally observed that as soil depth increased the quantity of SOC as ROC decreased. Follet et al. (1997) have reported similar results.

Soil OM contributes beneficially to soil properties and behaviour therefore, its accumulation in soil is critical. Soil organic matter (SOM) has received additional attention according to Schlesinger (1997) because it's influence on climate change globally and the magnitude of terrestrial soil organic matter in global $C$ sequestration. The balance between net input (plant wastes) and net output (erosion or respiration) is the quantity of SOM. Thus increase OM input or decrease degradation, are favourable for agricultural management strategies. Positive effects of no-till on SOC sequestration have been reported by many researchers. The works of Franzluebbers et al. (1994); Jastrow and Miller (1997) showed that no-till increased soil organic matter storage compared to conventional tillage (CT) due to decreased soil disturbance. The benefit of no-till to carbon sequester is however less because earlier researches showed that soil organic carbon content reach new equilibrium or peak after 10 years or more of imposition. West and Post (2002) in summarizing global data, reported that the rates of $C$ sequestration could reach its peak in 5 to 10 years, with soil organic carbon equilibrium attaining in 15 to 20 years with a change from CT to NT.

The quantity of SOC and the rate of carbon cycling have been found to be influenced by agricultural management practices. Donigan et al. (1997) showed that on global climate increasing greenhouse gases in the atmosphere have led to increased awareness in the soil carbon cycle, with interest on the benefit for increasing soil carbon sequestration. Decreases in $\mathrm{OC}$ content of arable soils through conventional tillage (CT) increased the rates of decomposition and redistribution of carbon (Christensen 1996). Paustian et al. (1997) observed that management practices such as increased use of plant wastes; RT; conversion of land to perennial vegetation and reduced bare fallow mitigated the reduction in OC. While No-till (NT) was found to improve soil organic carbon sequestration in many works of Bayer et al. (2001); Campbell et al. (1991) and Franzluebbers et al. (1994). Furthermore Campbell et al. (1998) observed that when cropping intensity increased C sequestration was enhanced. Also Angers and Carter (1996) found out that different management practices in agricultural systems affect the quantity and turnover of soil organic matter. In comparison to conventional tillage (CT), Franzluebbers et al. (1995a) reported that no till altered the distribution of crop wastes input, changes in soil aggregates and ecosystem. Cultivation cause soil structure decline by destroying soil macro aggregates exposing protected organic matter to microbial degradation (Cambardella and Elliott 1993; Nweke 2015a; Nweke and Nnabude 2014a).

Tillage accelerates decomposition through incorporation of crop wastes in soil matrix. No-till tend to leave much residues cover on the soil surface; this reduces the exchange energy and gas between the atmosphere and the surface of soil. These decreases were observed by Franzluebbers et al. (1995b) and Grant et al. (1997) to increase soil $\mathrm{H}_{2} \mathrm{O}$ content and decrease soil temperature thus, enhancing carbon storage. The rate of formation and decomposition of macro aggregates (aggregate turnover) was observed by Six et al. (2000) to have reduced under NT when compared to CT. This caused formation of micro aggregates that are stable and in which $\mathrm{C}$ was sequestered long period of time. C sequestration was reported by Gregorich and Janzen (1996) to have been enhanced by plant wastes and decrease in SOM degradation in agricultural environment. Positive relationships have been reported by Hassink et al. (1997) between plant residue inputs and SOC that is increasing cropping intensity increases plant residue input.

Many research works have recorded significant changes in some chemical properties over long periods of time. Studies like that of Ismail et al. (1994; Lal et al. (1994) and) Rhoton (2000) showed that surface soil layer after 4-28 years conversion to no-till significantly increased soil organic carbon content. The quantity of 
rain fall in a given location however influenced the period it will take to observe changes in soil properties. In locations with high precipitation and soils with low buffer capacity, soil acidity is very much observed (Poss et al., (1995). Bowman and Halvorson (1998) opined that in arid soils which are basically alkaline soils, that soil acidity can be increased with the use of urea and ammonium fertilizers in comparison with no fertilizer application. In Nebraska in a wheat-corn fallow rotation the $\mathrm{pH}$ of the $0-5 \mathrm{~cm}$ top soil when $\mathrm{NH}_{4} \mathrm{NO}_{3}$ or anhydrous $\mathrm{NH}_{3}$ was applied was found by the authors after nine years to be 5.0 with annual application of $112 \mathrm{kgN} / \mathrm{ha} ; 5.4$ when $84 \mathrm{kgN} / \mathrm{ha}$ was applied; 5.8 with annual application of $56 \mathrm{kgN} / \mathrm{ha} ; 6.2$ after annual application of $28 \mathrm{kgN} / \mathrm{ha}$ and 6.3 when there was zero (0) application of $\mathrm{NH}_{4} \mathrm{NO}_{3}$. Poss et al. (1995) was of the view that soil acidification range between $0-20 \mathrm{kmol} / \mathrm{h}$ h in a variety of agricultural systems and weather conditions.

According to the work of Poss et al. (1995) soil acidification is being affected by agricultural lime and acid rain deposition and cycles of iron; aluminium; manganese; carbon; nitrogen and sulphur. Long term acidity in most soils the contributions of iron; aluminium; manganese; carbon; nitrogen and sulphur distributions are less and often being ignored when computing for soil acidity rates. Poss and his companions' reiterated that ammonium-based fertilizers when applied nitrogen distributions plays a major role in the acidity of arable soils. The acidity of soils receiving $\mathrm{NH}_{4}$-based fertilizer is influenced by the plant $\mathrm{N}$ fertilizer uptake efficiency. Bowman et al. (1995) stressed that soil acidification as a result of nitrification can only be neutralized by the release of hydroxyl as nitrate is being picked up by crop plants. Soil acidity occurs when $\mathrm{NO}_{3}$ is lost as a result of leaching from the soil zone and in semi arid Australia under wheat cropping systems soil acidification rate was found to be between 1.4-21 kmolH/ha (Poss et al., 1995). The acidification result according to their studies was based on the $0-25 \mathrm{~cm}$ depth of soil treated with $\mathrm{N}$ as diammonium phosphate annually and $157 \mathrm{~kg} \mathrm{~N} / \mathrm{ha}$ rate of urea. Their studies however emphasised that the limited losses of $\mathrm{NO}_{3}$ below the root zone were responsible for the near neutral acidification in the root zone.

In wheat-corn fallow rotation study, Lilienfein et al. (2000) found soil acidification to be higher under notill when compared with its value in conventional tillage, the same observation was equally made with other crop production systems. Soil acidification under no-till and conventional tillage practices are attributed to many factors of which result in differences in the two practices. These factors are;

1. Halvorson et al. (1999) found out that in regions prone to drought such as in central great plain it becomes necessary to assess the effect of using much nitrogen based fertilizer on soil $\mathrm{pH}$ to notill practice in comparison with conventional till practice because of the waste cover in no-till practice that has the ability to increase productivity from $\mathrm{H}_{2} \mathrm{O}$ availability.
2. Changes in biomass production and grain yield was observed to have varying $\mathrm{C}$ cycle effects (Bordovsky et al., 1998; Bonfil et al., 1999; Halvorson et al., 1999) in water-limiting environments, NT have greater grain yields on the average than conventional tillage because of the crop wastes effects on soil $\mathrm{H}_{2} \mathrm{O}$ retention. The change in production practice between notill and conventional till causes anion exports in grain and accumulation of crop wastes under no-till. According to the report of Heenan and Taylor (1995); Lilienfein et al. (2000); Jacobsen and Westerman (1991) soil acidification result from changes in wastes in the soil horizon of notill and conventional tillage practice.

3. Increased nitrate leaching through the soil may be observed under no-till due to higher quantity of $\mathrm{H}_{2} \mathrm{O}$ retained (Bowman et al., 1995). This is as result of change in quantity of $\mathrm{H}_{2} \mathrm{O}$ leaching through the soil horizons. These factors also affect soil acidification at deeper depth.

The studies on the impact of NT and conventional tillage on soil chemical parameters conducted in semiarid dry land production systems were compared. The result showed that changing from wheat fallow rotation under no-till in Great Plains increased soil organic carbon of top soils (Sherrod et al., 2003; Bowman et al., 1999). The higher soil organic carbon observed with no-till was attributed to reduction in tillage operations and increased $\mathrm{H}_{2} \mathrm{O}$ storage that increased the quantity of crop biomass retained on the soil surface. Some other studies by Jaiyeoba (2003) and Ciotta et al. (2003) showed that cation exchange capacity in CEC in the top soils of no-till method increased compared with conventional tillage method due to increased soil organic carbon. Bowman et al. (1995) opined that exchangeable bases decreased in soils that do not receive agricultural lime as a result of acidification. This was noted by Singer and Munns (1999) to have been as a result of depletion of exchangeable bases on the exchange sites on organic matter and clay by $\mathrm{Al}$ and $\mathrm{H}$. Thus changes in soil acidification between no-till and conventional tillage methods can as well result in changes in exchangeable bases.

Soil chemical properties classified as chemical indicators are soil $\mathrm{pH}$, SOM, inorganic potassium, phosphorous and nitrogen, total organic nitrogen and carbon. Soil and crop management systems in practice, SOM and soil organisms' activity are influenced by soil $\mathrm{pH}$ and nutrient availability. The work of Scow et al. (1994) at UC Davis when they measured soil nutrient status and microbial parameters in 4 contrasting crop management systems over 4 years at the sustainable crop systems. Their findings show that soil $\mathrm{pH}$ and total nitrogen content were constantly less in conventional plots than the organic and low input plots. They observed also that phosphorous and potassium levels were greater in the organic material amended plots. Electrical conductivity (EC) an index of soluble nutrients 
in soil is explained as the amount of cations and anions in soil solution according to Smith and Doran (1996) was found to be linked with salinity of soil. Furthermore their findings showed that low level of electrical conductivity result in soil poor in nutrients. This kind of soil is very unstable and disperses easily, while high level content of electrical conductivity indicates soil with salinity problems. According to Brady and Weil (1999) a dynamic and complex part of soil properties called SOM influence greatly biological, chemical and physical properties of soil and their characteristics in a given ecosystem. Thus, changes in soil management according to Kennedy and Papendick (1995) is greatly influenced by sensitive indicators such as organic carbon and nitrogen, these are parts and parcel of soil microbial biomass, energy sources and active component of SOM.

Bolinder et al. (1998) attributes soil organic nitrogen as the major sensitive attributes of soil OM to conservation tillage system. It was found that very sensitive to soil management systems though their sensitivity was location specific were macro-organic carbon, microbial biomass carbon and light fraction carbon. Soil OM is the seat of productivity as fertility is biologically active SOM (Wander et al., 1994).

\section{Effect of Tillage Methods on Soil Biological Properties}

Research reports from temperate region's soils showed that enzyme activities decreased with depth (Bergstrom et al., 1998), there was also report of soil enzymes stratification on NT, experiment on cooler soils showed multiple enzymes sensitive to tillage methods (Bergstrom et al., 1998; Kandeler et al., 1999). In some Austrian mollisols Kandeler et al. (1999) found out enzyme xylanase change rapidly than the activities of phosphatase and protease enzymes. This indicates that differences in crop and soil management affect some enzymes rapidly than others. The sensitivity of soil enzymes to management practices are also influenced by climatic, abiotic and biotic factors. Many microbiological properties such as dehydrogenase activity was observed to reduce with soil depth being greater in surface soil (Melero et al., 2008; Madejon et al., 2007; Gren et al., 2007; Roldan et al., 2005). Ajwa et al. (1999) found burning of plant wastes significantly decreased enzyme activities and microbial biomass.

Garcia et al. (1997) and Truu et al. (2008) found correlation between microbial biomass measured by soil respiration and total organic carbon to be statistically significant. Higher enzyme activity, organic carbon, microbial biomass values were recorded in conservation tillage methods as against low levels observation in conventional tillage methods and in arid and semi-arid weather conditions on which much experiment were conducted under short and long term basis (Angers et al., 1993; Mullen et al., 1998; Roldan et al., 2005; Madejon et al., 2007). Greater numbers of spores of mycorrhizal were recorded under reduced till and no-till compared to conventional managements (Galvez et al., 2001; Anken et al., 2004; Borie et al., 2006; Li et al., 2007). Tillage according to McGonigle and Miller (1999) disrupt hyphae network of mycorrhizal this tend to decrease the efficiency and soil inoculation potential .The hyphae network was observed by McGonigle and Miller (1999) to have been rendered none effective by breaking apart the soil macro-structure. Mycorrhizal spore density and SOM have been found by Guo and Han (2008) to be positively correlated. In agricultural ecosystem soil quality indicators according to Dick (1994) can be assessed using microbiological properties. Soil enzymes as noted by Sikora et al. (1995) originated either from plant, animal or microorganisms they carry out the metabolic processes of all these organisms. Balota et al. (2004) noted that soil enzymes are catalyst to numerous metabolic reactions in soil organism existence, nutrient recycling, OM formation and decomposition and soil structure formation. Researchers have shown that soil respiration and phosphate concentration in soils increased significantly with organic wastes treatment but with chemical fertilizer treatment phosphate increased significantly in soils because phosphate from wastes are very dynamic as against those from chemical fertilizer that are less mobile (Kanchikerimath and Singh 2001). Shakin and Dindal (1997) observed reduced earthworm population in tillage methods (conservation and conventional tillage) of which they attributed to soil compaction cause by machines used for crop production. While Langmaack et al. (2002); Kreuzer et al. (2004) and Laurent et al. (2004) observed that $\mathrm{N}$ is very homogenous in various soils depth studied in conventional tillage as against CT of which the authors attributed to be due to the earthworm activity. Nutrients uptake mainly phosphorous, plants with fine roots as found in grasses are found to be more efficient in P uptake in soil (Marschner and Dell 1994). The roots are characterized by having arbuscular mycrorriliza (AM) association. In all of the major terrestrial biomass arbuscular mycorrhizal symbioses are formed about $80 \%$ of vascular plant species.

Smith et al. (2010) noted that their functions are particularly important in sustainability of crop production with reference to water stress and nutrient deficiency. Biotic interactions with their symbionts are dependent on air and soil temperature that invariably increase plant community (Bunn et al., 2009). Arbuscular Mycorrhiza (AM) associations have been studied in many tropical plants (Bisht et al., 2009; Feddermann, et al., 2010). While Becerra et al. (2009) studied arbuscular mycorrhizal spore numbers and its colonization on herbaceous crops, pines, shrub and fruit tree.

Tillage systems tend to have different kinds of effect on soil properties, nutrient recycle and mobility and soil micro-organism. Espana et al. (2002) reported changes in soil $\mathrm{H}_{2} \mathrm{O}$ storage, air and heat and these influences residues decomposition in the soil, the scenario are however dependent on the extent of soil perturbation by tillage methods. These changes also affect micro-organisms in their numbers, diversity and 
activity. Hence reduced and no till systems reduce soil perturbation; improve soil structure and SOM content compared with conventionally tilled soils (Carter 1992; Franzlubbers et al., 1995 and Franzlubbers 1999). The influence of tillage practices on soil properties changes were studied in a long- term researches (Lal et al., 1994; Garcia et al., 1997; Gomez et al., (2001) and conclusion was made that half a decade is practically okay for dictating change in soil characteristics. Soil management practices involved can influence conditions for soil organisms necessary in nutrient cycling and $\mathrm{OM}$ degradation (Clapperton et al., 1997). Soil microbial biomass is a labile pool popularly used to assess change in soil organic matter. Similarly, Balota et al. (2004) after 2 decades of study on Oxisol in Brazil in all crop production systems studied reported increased SMB in no-till compared with conventional till across all soil depths studied. The highest change between no-till and conventional tillage however, occurred in top soil layer of 0 to $5 \mathrm{~cm}$ depth. Therefore tillage affected soil microbial biomass and the community. Frey et al. (1999) in the southern USA found out 0 to $5 \mathrm{~cm}$ surface soil to have fungal abundance of which was noted to be significantly greater in no-till compared to conventional tillage in every locations studied and that higher presence of bacterial was only noticed in 2 of the 4 locations. They further observed that the abundance of bacteria or fungal were not significant at soil depth of $5-15 \mathrm{~cm}$. Using phospholipid ester- linked fatty acid (PLFA) method, Feng et al. (2003), noted that the SMB change severally with soil depth to a higher bacteria number in soil. These changes in soil microbial biomass was found to be the cause of differences in crop wastes return and the soil body resulting from different tillage practices.

Mycorrhizal hyphae of which assist in $P$ availability in soils and soil pore network are found to be affected by conventional (McGonigle and Miller 1996). The machines and implements used in conventional tillage methods cause a lot of harms to micro organisms and create an environment that directly or indirectly affect their activities, it crushes their nets and tunnels; lower their proliferation in soil, they die as a result of little or no organic materials in soil surface, unfavourable temperature and soil moisture. The total OM proportion present in MB was suggested by Carter (1992) to be a good measure for detecting changes in soil biological properties caused by tillage treatment. He compared 1040 years study of the OM changes in tillage treatments to long-term conditions in grassland fields. He was able to determine the ratio of carbon biomass to total organic carbon in the $0-5 \mathrm{~cm}$ soil layer in range treatments like chisel ploughing, direct drilling, and shallow tillage. Their result findings showed that $\mathrm{OC}$ was associated to MBC and $\mathrm{OC}$ proportion in the biomass of the tillage treatments was higher in ploughed fields of which was like the value obtained in grassland fields. The recycling of soil biological indices in soil, in a way that microbial nitrogen biomass and carbon biomass increased in the 0 - $5 \mathrm{~cm}$ soil depth by $10-23 \%$ was found to be caused by reduction in soil tillage.
Small-input and organic wastes practices are different in nutrient dynamics compared with conventionally managed systems. Improved nutrient status of soil through the knowledge of soil micro organism proliferation was sought out by Gunapala and Scow (1998). Their findings showed that assessed nitrogen and carbon linked with the MB and extractable carbon in soil depth of $0-15 \mathrm{~cm}$ were statistically higher 93 ugg $^{-1}$ and 105.9 ugg $^{-1}$ when compared with conventional tillage practice of $47.4 \mathrm{ugg}^{-1}$ and $5.4 \mathrm{ugg}^{-1}$ systems. Though extractable nitrogen was found to be higher in wastes amended and small input treatments, this was observed to be true in CT, but the inverse recorded in organic method. They attributed the result to the constant release from micro organism plant-available $\mathrm{N}$. Organic treatment increase SOM 1.5\% times higher than the fallow method with MB estimates correlated significantly with SOM. By measuring soil respiration immediately following tillage Calderon et al. (2000) studied tillage impact on SMO. When simulation of tillage was done by sieving soil cores intact and $\mathrm{O}_{2}$ assessed a day and for 14days through sieving by incubation, it was observed that $\mathrm{O}_{2}$ reduced rapidly after sieving and continued in the next 2 weeks of which the experimenters noted to be due to response of soil to moisture reduction. The evolution of carbon iv oxide was found out to be an important index of microbial biomass; but does not show microbial population diversity. Plant growth promoting rhizobacteria (PGPR) is another method used to select microorganisms' populations and associated with plant suppression of disease. Pieterse et al. (1996) observed that plant growth promoting rhizobacteria without causing themselves any systems through systematic resistance protect crops against pathogen infection. Carter and Stewart (1996) reiterated that conventional tillage practices degrade soil ecosystems. Soil quality index according to Karlen et al. (2001) depend on physicochemical and biological properties of soils. The following are soil quality indices, soil structure, soil water relations, soil compaction, water infiltration, and erosion protection as well as chemical and biological status are influenced by soil OM.

\section{Response of Crops to Tillage Methods}

Tillage is all soil related operations necessary for good seed bed preparation that will ensure seed germination and crop growth. Tillage influence varies from one agricultural zone to the other. Hence moisture conservation is considered major factor in semi-arid regions. Soils react differently to tillage systems and due to this effect on crop yields are the same with crop types in the same farm and locality. The management of crop residues in semi-arid zones influences moisture conservation and tillage effects. In semi-arid zones, Unger et al. (1991) recognized the link between tillage system and residue management as the practices that have major influence on soil conservation. According to Ohiri and Ezumah (1990) the fertility of soil which can 
manifest in poor or good crop performance can be influenced by soil manipulation. Conservation tillage improves soil productivity and limits degradation (Parr et al., 1990) conservation tillage may be regarded as minimum tillage, mulch tillage, reduced tillage and no tillage (Antapa and Angen 1990; Opara-Nadi 1990; Unger 1990; Ahn and Hintze 1990). One major importance of conservation tillage is its effectiveness for controlling erosion. Seed bed preparation requires that grass should be cleared with a cutlass, trees and shrubs pruned and residues disposed of by burning in situ (Aina et al., 1991), this type of clearing they noted gives soil structural stability for one or two years said because of appreciable cover and the root system left on the surface of soil. The NT practice seems to have broad application according to Aina et al. (1991) in sub-humid and humid locations, 4-6 tha ${ }^{-1}$ of crop waste used as mulch are adequate. Considering various methods of tillage like NT, MT, RT and CT, Rashidi and Kreshavzarzpour (2008), observed that each tillage methods studied significantly influenced crop yield, dry biomass of root, length and diameter of fruit, fruit weight and soluble solids but statistically no difference in diameter of plant/hectare, fruits number/plant and length of root. Each crop is favoured by a different tillage method.

The tillage method which affects the soil physical properties can also impair the penetration of the crop root, the growth, the fruiting and duration of the crop. Therefore the best tillage method of one plant can adversely influence the other plant and soil properties. The authors also found more adequate and beneficial tillage practice to be mould board plough followed by two passes of disk harrow in enhancing soil traits and yield of crop due to decreased soil physical properties and soil compaction, increased water content of the soil, improved seed soil contact and suppressed weed growth. Tillage methods influence soil resources sustainability due to its effect on soil characteristics. Lal (1993) stated that good tillage methods enhance soil properties, inappropriate tillage cause degradation of soil structure and organic matter, accelerated erosion, plant nutrients depletion and disruption in cycles of water. Conventional tillage methods according to Keshavarzpour and Rashidi (2008); Rashidi and Keshavarzpour (2008) influenced strongly soil bulk density, penetration resistance and water content. Conventional tillage as against conservation till and notill methods produce fine soil tilth that leaves the soil intact (Rashidi and Keshavarzpour 2007; Rashidi et al., 2008) the difference between the tillage methods results in distribution of pore sizes that enhance the efficiency of soils to accumulate and release agricultural chemicals, $\mathrm{O}_{2}$ and $\mathrm{H}_{2} \mathrm{O}$, enhance soil water content and porosity of the soil.

This according to Khan et al. (2001) and Kurshid et al. (2006) leads to nutrient use efficiency, good crop growth, and runoff and erosion control. Conservation tillage methods, decreased pore spaces, increased soil strength and aggregates stability (Horne et al., 1992; Hill 1990). Conventionally tilled soil is associated with pore network due to root channels, vertical cracks and earthworms. Conservation tillage decreased continuous disruption of soil pores. Reddy et al. (2007) estimated $\mathrm{CO}_{2}$ evolution from soil and observed higher $\mathrm{CO}_{2}$ in conventional tilled soils than no-till soils of which confirmed greater C storage in NT soils, the effect of conservation tillage and NT practice on crop yields however, are inconsistent (lqbal et al., 2005). Conservation tillage and no-till system in arid lands of Iran was reported to have shown a devastating effect on crops yields (Hemmat and Taki 2001; Kesharvarzpoor and Rashidi 2008; Kesharvarzpoor and Rashidi 2008). Chaudhary et al. (1992) observed $\mathrm{H}_{2} \mathrm{O}$ retention and notillage has $13 \%$ income on investment compared to conventional and conservation tillage methods.

On poorly drained, fine-textured soils yield decrease were reported in no-tillage practice (Dick et al., 1991; Opoku et al., 1997), especially in sole corn (Chase and Duffy 1991). In a research by Moncrief et al. (1990; 1991) in Minnesota, USA, sole corn in no-till yields $15 \%$ reduction when compared with corn - fallow yield on a soil poorly drained. Tillage effects on yields are noted by Griffith et al. (1993) to be a factor of weather, soil type and drainage. Past study with regard to tillage methods throughout the USA by several workers indicated that on well drained soils yield of corn with crop rotation in southern latitudes were higher in NT compared to CT methods (Dick et al., 1991; Griffith and Wollenhaupt 1994; Morrison and Chichester 1994; Mclsaac et al., 1990; Chase and Duffy 1991) and this account for change in climate conditions. Also some long-term experiment (greater than 10 years) were performed by Kapusta et al. (1996); which were majorly centred on tillage effect and crop rotation on maize parameters showed plant height, availability of moisture and application of fertilizer in NT not to be lower sometimes than the ones in CT (Beyaert et al., 2002; Hussain et al., 1999; Kapusta et al., 1996), however crops in NT often are smaller in height compare to CT ones at early growth. Even at that, height of plant may not be correct morphological assessment for yield decrease in NT maize. Rather variability in height of plant in NT systems could be an ideal indicator of yield decrease because uniformity of plant height has been found to be linked with greater yields in maize. While some researchers have reported that yield losses in maize result from emergence variability (Ford and Hicks 1992; Liu et al., 2004), because plants that earlier emerged have competitive advantage over later emerged ones for light, $\mathrm{H}_{2} \mathrm{O}$ and this caused increased height variability of plant (Nafziger et al., 1991; Ford and Hicks 1992; Pommel et al., 2002; Liu et al., 2004).

Franzluebbers (2002) observed that effect of erosion, water infiltration and nutrient conservation on near soil surface help in understanding management effects on the soil. Good soil quality enhance crop yield, animal and human health and ensures environmental quality as was reported by Action and Gregorich (1995). Tillage is important part of agricultural production system that alleviates soil constraints according to Arshand et al. 
(1999). Tillage systems as reported by Ganjri et al. (2002) involve processes done sequentially on field to improve crop production activity. The responses of yield to tillage are a factor of history of the field and year's tillage method that has been performed on the particular field. Increase in yield without tillage over a period depend on so many factors; the work of Langdale et al. (1990) noted that much activity of organisms at top soil surface, due to increased OM, influenced their results findings. Conservation tillage effects on properties of soil are associated with mulching. Tillage practice by conservation method in which part of the soil remain uncovered like ridge cropping, stubble farming and till farming, their effect on the properties of soil could be an intermediate between conventional till and no-till. At Abakaliki in Nigeria, effect of no-till at various soil depths was studied by Ogbodo (2005) and the findings from his results showed that at tillage depth of $0.40 \mathrm{~m}$, there was increased potato yield to the tune of $14.5 \mathrm{mgha}-1$, drainage, penetration resistance and decreased BD. The gains of conservation tillage adoption were observed by Uri (1999) to depend on soil behaviour, local weather, cropping systems, and farming operations.

These benefits reduce soil productivity; fertility and manure losses by $\mathrm{H}_{2} \mathrm{O}$ erosion and according to Benites (1997) enhance better use of $\mathrm{H}_{2} \mathrm{O}$ and soil resources, reduce the costs of fuel for land preparation and reduce man labour. Human and livestock movement, influence of precipitation, and cycles of change in drying and wetting as reported by Anikwe et al. (2003) can change a conventionally tilled soil to pretillage bulk densities. Researchers like Arrioga and Lowery (2003) argued that enough $\mathrm{H}_{2} \mathrm{O}$ is necessary for crop development, and that $\mathrm{H}_{2} \mathrm{O}$ storage is very important in plant development. Andraski and Lowery (1992) have stressed that the highest influence on the productivity of soil is change in water-holding capacity and rooting depth of crops. Tillage affects water storage in soil higher than canopy formed by various crop species. Soil water storage is influenced by tillage due to differences in level of $\mathrm{H}_{2} \mathrm{O}$ movement in the soil, evaporation and run-off, revert liquid into vapour at any temperature below its boiling point according to Fabrizzi et al. (2005). Dao (1993) and Calvino (1998) attributed rise in $\mathrm{H}_{2} \mathrm{O}$ content in no-till plots to decreased water removal by evaporation, soil protection from precipitation and higher infiltration. Warkentin (1995) reported soil organic matter because of its effect on the properties of soil has made nutrient and carbon highly studied soil function an influential sign for soil productivity.

Many studies of Langdale et al. (1992); Anikwe et al. (2003) and Cambardella et al. (2004) have proved that conventional till methods lead to loss of SOM and decreased nutrient supplying efficiency. Reicosky et al. (1995) reported that recycling of wastes from the top soil to higher soil depths is the main drawback of tillage on soil. The redistribution of $\mathrm{OM}$ enhances reduction in $\mathrm{H}_{2} \mathrm{O}$ movement into soil, rise in water evaporation and reduction in use of water as was reported by authors like Langdale et al. (1992); Mielke and Wilhelm (1998).
Wezel et al. (2000) opined that losses and gains in total nitrogen and phosphorous are majorly controlled by SOM. In short term studies by Anikwe et al. (2007) showed there was greater sweet potato yield in conventional till relative to no-till; the authors attributed yield advantage to lower bulk density observed in CT plots that enhanced soil air, thermal regime, root proliferation, and quicken $\mathrm{Om}$ degradation and mineralization which provide good conditions for the crops. Soil constraints that affect yield increase must be eliminated by a tillage method according to Arshad et al. (1994), for a confident change on crop establishment and yield.

Studies conducted by Tessier et al. (1990) showed differences in water content of soil as a result of tillage practice are not strong enough to affect plant yield. Larson (1999), in his experiment to determine tillage requirement for corn production stated that some properties that are used to estimate the impact of tillage methods on a wide soil is not workable due to lack of knowledge, weather of the area, plant species and soil combinations. If soil is annually ploughed, crop roots proliferate $10 \mathrm{~cm}$ below more in NT method while intermediate root proliferation happens with minimum tillage systems. When crop wastes are removed, there is higher root development in the $15 \mathrm{~cm}$ soil layer. In some soils, no-tillage can cause some restricted root growth because of increased bulk density compared with conventional tillage. Awodun and Ojeniyi (2002) observed that crop yield and fruit weight are significantly affected by tillage systems studied, although in the other tilled plots such as heap and bed considerable good performance were observed on the total parameters. This, they attributed to better uptake of nutrient especially phosphorous which result due to mineralization of organic matter when mixed with soil during tillage, loosening of soil enables root development and nutrient uptake below the soil surface due to downward movement of the roots that absorb nutrients. Soil infiltration rates, soil BD and penetration resistance depends on depth of tillage this help to show case changes in crop development, yield in quality and quantity (Hamza and Anderson 2002, 2003, 2005). In actual sense, every tillage method reduce soil BD and penetration resistance to the tillage depth and rate of $\mathrm{H}_{2} \mathrm{O}$ movement into soil higher in cultivated soil relative to uncultivated soil (Evbach et al., 1992; Ferreras et al., 2000).

For example Alamountia and Navabzadeh (2007) observed tillage that is deep have much influence on $\mathrm{BD}$, water intake rate; $\mathrm{OC}$ and yield of crop relative to shallow tillage and semi- deep practices. The authors then concluded that these parameters increased with increasing depth of ploughing. Popp et al. (2002) in their studies on deep tillage systems reported in consistency of crop yield to tillage that is deep. Moreover, Richard et al. (1995) reported decrease in sugar beet yield in a tillage that is shallow and less crop density was associated with direct-drilling. Kouwenhoven et al. (2002) attest that sugar beet yield was 9\% decreased 
reduced tillage of $12-18 \mathrm{~cm}$ depth relative to mould board ploughing of $20-30 \mathrm{~cm}$ depth. Carter and Ivany (2006) reported increased weed species population and diversity with conservation tillage methods and according to Borresen (1993) have a harmful effect on crop yield. Tillage systems could be superior weed control method that enhanced soil productivity, this empowers crops to compete for nutrients, $\mathrm{H}_{2} \mathrm{O}$ and light with the weeds (lqbal et al., 2005; Romaneckas et al., 2006; Rashidi and Keshavarzpour 2007; Rashidi et al., 2008; Adamaviciene et al., 2009; Romaneckas et al., 2009; Rashidi and Khabbaz 2009; Jabro et al., 2010).

Conservation tillage practice cause poorer quality soil and increase unwanted plant population and diversity as was observed by Hill (1990); Horne et al., (1992); Borrensen (1993) and Carter and Ivany (2006). Babalola and Olaniyi (1999) and Adeoti and Olarewaju (1990) worked on the influence of soil tillage practices in northern guinea savannah and derived savannah of Nigeria respectively, observed statistically significant greater tomato yield in CT as against NT practice. Adekiya et al. (2009) studied the influence of 5 tillage systems on an Alfisol and observed $16-62 \%$ increased tomato fruit yield with ploughing followed by harrowing and ridging when compared with the values from manual clearing and mounding. They attributed their results on the type of soil studied and weather condition. Thus according to the authors, it appears that the effects of tillage system on tomato yield may depend on the environment and soil type. Tillage systems as opined by Ahmed et al. (1996) contributes $20 \%$ of the production factors among the controlling options for remediation of soil and compaction of subsoil, Motavalli et al. (2003) opined that it influence tillage depth and crop rotations. Deep tillage enhances water movement into the soil, root proliferation and development, breaks soil layer of high density and increase grain yield of crop. The works of Materechera and Mloza (1997) showed that hard compact layer develop below $25 \mathrm{~cm}$ depth ridges in both conventional tillage and minimum tillage. Soil on ridges of conventional tillage had constantly decrease penetration resistance than did minimum tillage. Bonari et al. (1994) in his own studies observed that grain yield was significantly higher with chisel ploughing than shallow disk and deep ploughing. Albuquerque et al. (2001) observed that in no-till system plant height, number of leaves and grains per ear were reduced compared with conventional system. Evaluating the impact of various tillage methods on cowpea plant Olaoye (2002) reported highest pods number and grain yield in flat-field (no-till) and disk harrowing. Seven different tillage systems were studied by Ojeniyi (1997) on the growth and yield cowpea on Alfisols in the grain forest zone of Nigeria, their study revealed that no-tillage produced taller plants and higher grain yield compared with disk ploughing and disc harrowing. The influence of tillage methods like flat field (NT) ploughing, harrowing mounding and ridging on vigna unquiculata (cowpea) plant, growth and yield parameters in Ferric luvisol was studied by Kombiok et al. (2005) in guinea savannah area in northern Ghana. Their result showed that disc ploughing and disc harrowing improve cowpea yield against the value obtained from no- tillage methods.

Similar result was equally reported by Rashidi and Kesharipour (2007) under clay-loam soil evaluated seven tillage treatments effects on grain and yield parameters of maize and reported significantly greater grain yield of maize under tillage treatments. In derived savannah agro-ecological zone of Nigeria, under ferrisol, ferruginous soils Olaoye (2002) in contrast reported significantly higher cowpea with ploughing and harrowing. Agbede et al. (2008) as well in their studies reported greater sorghum yield in the no-till treatment in comparison with the ploughing followed by harrowing treatment. However, Onwueme and Sinha (1991) and NDSU (2008) observed soybean seedlings emergency to reduce drastically if depth of seed sowing exceed $5 \mathrm{~cm}$. Ridge, a tillage method as put forward by Rowland (1993) is a minimum tillage (MT) that combine the effect of series of tillage operations in one operation to improve seed germination and growth. The author further emphasised that mound and ridge method conserve soil and water, air circulation and these facilitates yield improvement of pods of legumes as well as roots and tubers. Sowing of crops on beds, strip tillage, zero tillage, crop rotation management, plant residue management etc are different crop cultivation practices refer to as conservation agriculture.

Lal et al. (2007); Limon-Ortega et al. (2002) and Egamberdiev (2007) observed that excessive tillage cause dispersion of soil aggregates; reduce OM mineralization in the soil, evaporation and soil salinity levels. The use of raised beds was observed by Pulatov (2002) to conserve soil and irrigation $\mathrm{H}_{2} \mathrm{O}$, enhance root establishment and for root to move deeper in to soil. Report from FAO (2006) showed that farmers in many countries in recent years increase crops planted on beds. Sayre (2006) observed seed bed for grains and the likes create a good space in between seedlings enough for human and machine traffic for farm operations necessary for the plant establishment. However, for a crop like wheat according to Sayre and Hobbs (2004) good spaces is needed in order to encourage the crop compete for nutrients, sun rays and $\mathrm{H}_{2} \mathrm{O}$, space with weeds on bed.

Aggregates size decrease rapidly from too much tillage this increase the rate of soil crusting, compaction, erosion and yield reduction reason being that smaller aggregates are less stable to the agents of denudation. The effects of various tillage practices on soil aggregation haven been conducted by many workers under varying conditions. Four-year tillage study on a Gray Luvisol Malhi et al. (2006) found on no-tillage system compared to other tillage practice studied smallest percentage of wind-erodible aggregates, greater percentage of large aggregates and highest mean weight diameter of dry soil. Bulk density is a physical property of soil and high bulk density is an index of compacted soil. Stoscopf (1981) is of the opinion that soil bulk density range of 1.46 to $1.66 \mathrm{Mgm}^{-3}$ are very 
compact for easy root penetration and proliferation in soil and improved crop yields. Mohanty et al. (2007) in India, reported reduction in yield of rice with increased $B D$ in NT of rice/wheat method. When the authors conducted regression analysis on their findings, it attests to significant reduction on the yield of rice and wheat with increased BD.

Many studies also evaluated the effect of various tillage practices on soil organic matter. These studies agree that reduced tillage can increase SOM. Three different types of OM exist in soil they are partially decomposed plants and animal residues, properly decomposed organic residues, known as humus and visible root system. A well drained aerated soil is an index of a dense, well-developed root system. The essence of maintaining soil $\mathrm{N}$ in the soils through soil structure maintenance is associated with the amount of partly decomposed organic matter. Humus though well mixed and stabilizes the soil is small to provide produce of decomposition according to Stoskopf (1981) that will help to stabilize the soil than fresh or partially decomposed OM. In tillage and crop wastes in rice/wheat method, Mohanty et al. (2007) found yield increase in both crops with increased OM through regression analysis. In Spain Hemanz et al. (2002) studied several tillage techniques on long-term research and reported increased $O M$ in $0-19 \mathrm{~cm}$ and $20 \mathrm{~cm}$ under zero tillage against $\mathrm{CT}$.

Intensive soil tillage reduces SOM and carbon and nitrogen which are basic components of organic matter. This implies that tillage can change the level of carbon and nitrogen contents of soil. The research conducted in Canada by Malhi et al. (2006) with different crops and four cropping seasons under zero tillage observed higher masses of $O C$ and TN than with regular tillage practices. This they observed to be correct after 4 cropping systems. In a long-term experiment conducted in rain fed area of Mexico, Govaert et al. (2006) reported on zero tillage positive improvement of crop wastes, tillage and crop rotation relative to $\mathrm{CT}$. An investigation under different soil and climatic conditions has shown improvement in soil aggregates. This can be supported by the researches aforementioned. These works highlighted the influence of minimum tillage on SOM, bulk density, thereby stable crop yields.

Investigations conducted under rain fed conditions indicated that soil surfaces with much wastes form check against evaporation and alter microclimate of the crop environment (Sarkar et al., 2007). The implication of their study is that soil water depletion occurs at a slower rate with wastes than with bare soil. A three-year field study conducted by Gangwar et al. (2006) in Indo-Gangetic plains using 3 methods of tillage - zero till, CT, reduce/strip on rice/wheat found 5.1t/ha yield of wheat in reduced tillage, $4.75 \mathrm{t} / \mathrm{ha}$ in zero tillage and $4.6 \mathrm{t} / \mathrm{ha}$ in CT. Their studies attributed increased wheat yield in RT to adequate aeration, $\mathrm{H}_{2} \mathrm{O}$, small weed infestation and better germination as against conventional and zero tillage.
The studies in semi-arid Mediterranean conditions show that barley yield with nitrogen and NT practices can reach up to 4 mgha-1(Angas et al., 2006) of which is about $30 \%$ more than under conventional tillage. Though some researchers have shown that zero tillage methods influence crop production favourably, the method has some drawbacks. In studies in wet period, Monneveux et al. (2006) noted negative effect of NT on grain yield of maize of which was attributed to less number of grains per cob.

Beds and NT, with or without crop wastes, have been shown by Gupta et al. (2006) to delay plant development in short term investigation, but long-term investigations five-seven years show that the effect is less with soil quality improvement.

\section{Effect of Tillage on Soil Compaction, Erosion and Soil Strength}

Tillage along in association with management method in practice affects various properties of soil. These soil traits have been found to modify soil water transmission, erosion and runoff. A large number of authors have addressed the impact of soil and crop management practices on the following soil physical properties;

(i) Soil porosity (Logsdon et al., 1990; Lal et al., 1994; Shipitalo et al., 2000),

(ii) $\mathrm{H}_{2} \mathrm{O}$ holding capacity (Azooz et al., 1996; Lal 1999; Blanco - Conqui et al., 2004),

(iii) HC (Lal 1999; Blanco - Conqui et al., 2004),

(iv) rate $\mathrm{H}_{2} \mathrm{O}$ movement into soil (Van ES et al., 1999),

(v) Structural stability (Thorburn 1992; Pillai and Mc Garry 1999)

(vi) BD (Lal 1999).

Tillage operations performed under unfavourable climatic conditions according to Ankeny et al. (1990) can cause soil compaction. Intensive and unnecessary tillage practices deteriorate soil quality due to increased decomposing SOM and environmental quality. The greater the compactions of soil, the more adverse effects it will have on seed emergence, establishment, root development and plant yield. Lal and Shukla (2004) comparative effects of tillage systems influence properties like water infiltration, erosion and aggregate stability. Also soil compaction and strength are affected by soil properties like bulk density, size distribution, OM content and moisture content. Soil with more clay than sand according to Lal and Shukla (2004) tends to show more cohesion and strength. The uptake dose of soil reduce slightly in the compacted soils of no tillage rate, may be as a result of soil structure self repair observed in vertisols by Sharma et al. (1996). Water infiltration and bulk density are the indices of soil compaction (Evbach et al., 1992). In another experiment, $\mathrm{H}_{2} \mathrm{O}$ infiltration was found to be increased in tilled soil than what was found in soil not tilled (Evbach et al., 1992; Ferreras et al., 2002). Cetin et al. (2005) reported that soil compaction 
at certain soil depths helps to increase the soil pores number to retain water.

Soil compaction as reported by Van Landen (2000) is the most important agent of soil degradation in many arable soils. In soil that compacted, the particles are compressed, this cause reduction in openings necessary for air and water circulation adequate for crop establishment. The studies of Ohu et al. (1994) and Lampurlanes and Martinez (2003) showed that compaction are caused by heavy machinery used in the field, animals traffic and ploughing at particular soil depth for several years, reduction in OM application, and constant mineral fertilizer use. When soil compaction become intensive it creates a negative influence on water storage and flow, this restricts the soil volume explored by plant roots and delay root growth and development. This scenario has been reported by Stewart and Vyn (1994) and Zhang et al. (1997) to affect uptake of water and nutrients by plants.

Soil compaction is evaluated through soil bulk density measurements and penetrability. Soil mass per unit volume of soil is a particular soil property index for measuring root growth inhibition. The soil porosity water and biological activity in soil reduce as soil bulk density increase. Fuentes et al. (2004) observed that farm implements and animal trampling have destroyed soil pores and increased soil bulk densities and the soil resistance to penetration. The effects of soil compaction as reported by Ishaq et al. (2002) could be alleviated using sub-soiling, deep ploughing and chiselling, but these methods according to them are temporary as the soil settles back into place. Higher BD and penetration resistance was observed by Moreno et al. (1997) in conservation tillage compared to CT systems. Exchangeable ions and $\mathrm{OC}$ in the plough depth in soil samples according to Carter et al. (2002) were not significantly different among treatments. Strength of soil may be estimated indirectly by measuring the soil penetration resistance (Osunbitan et al., 2005). Soil penetration resistance is useful to estimate tillage impact on soil strength which indicates the ability of roots to explore the soil volume. Values over $2000 \mathrm{kPa}$ generally limit root exploration and so restricts nutrient and water uptake by crops (Fabrizzi et al., 2005), thereby reducing yield. Ishaq et al. (2002) found that penetration resistance was negatively correlated to grain yield of wheat $(r 2=-0.49, p=0.01)$.

Similarly, in the study by Materechera and Mloza-Banda (1997) the penetration resistance was negatively correlated to the root length density of maize $(r 2=-0.66, p<0.05)$ which affected overall plant growth. Ploughing loosens the soil and thus decreases soil strength within the plough layer. For instance, Fabrizzi et al. (2005) found that although penetration resistance in $30 \mathrm{~cm}$ soil layer is less than $2000 \mathrm{kPa}$ under both MT and NT the soils under NT have a consistently higher penetration resistance to a depth of $30 \mathrm{~cm}$ than soils under MT. A comparable study by Materechera and Mloza-Banda (1997) in Malawi showed that penetration resistance was greater when maize was planted on ridges made the previous season (MT) compared to newly constructed ridges (CT), and that root density was lower under MT. Ridges made the previous season were considered MT as there had been less soil disturbance than on the newly constructed ridges during the last season. Although tillage may initially lower the penetration resistance, ploughing decreases the SOM. This increases the likelihood of slaking and dispersion of soil particles and thereby increases the soil's susceptibility to become hard setting. Materechera and Mloza-Banda (1996) showed that by the third season of reduced tillage the soil had compacted sufficiently to adversely affect maize grain yield and that the penetration resistance was statistically greater than the soil which is tilled annually. As with bulk density, soil strength may be greater under CT than NT in the longer time. Osunbitan et al. (2005) observed eight weeks after tillage the penetration resistance in $0-5 \mathrm{~cm}$ soil depth decreased for no - till and increased in soils which were ploughed.

\section{Tillage influence on Water Retention, Infiltration and Holding Capacity}

The tillage practices in association with cropping system and soil water contents under field conditions required systematic analysis. The economic analysis of cropping systems and tillage operations could be used to develop an effective technology for agricultural sustainability.

Dynamics in soil pores especially with swelling clay soils are documented in the works of AnguloJaramillo et al. (2000) and Horn and Smucker (2005) in experiment of water and air flow. Self-healing of crackks accoding to Eigenbod (2003) and Mc Donald et al. (2006) is the explanation for change in soil disturbances observed in swelling clays, soil organic matter influence a lot of soil characteristics like favourable water uptake, aggregate stability, and nutrient mineralization, aeration, and retention properties. Soil organic matters as reported by Bolan et al., (2004) and Sial et al., (2007) increased portion of $\mathrm{H}_{2} \mathrm{O}$ available for crop growth and development through improvement in moisture holding capacity and physical characteristic of the soil.

Brady and Weil (1999) noted that available $P$, sulphur and $\mathrm{N}$ are primary source of most crops. The major soil quality traits associated to erosion by water, by Karlen and Stoott (1994) is to allow $\mathrm{H}_{2} \mathrm{O}$ entry into soil arrangement by infiltration. Rates of $\mathrm{H}_{2} \mathrm{O}$ infiltration is a major parameter for decreasing run off and for storage crop availability of $\mathrm{H}_{2} \mathrm{O}$, of which Logsdon et al. (1993) found to provide an indirect estimate on soil management affects on hydrological efficient macro porosity, soil density, and surface seals. Bruce et al. (1995) in comparison studies of CT and no - till observed that sorghum grain planted in no-till into crimson clover decreased erodibility of soil and increased infiltration of water into soil than CT. VerVoort et al. (2001) compared three positions (plant row, nontracked inter row, and tracked inter row) and tillage (Chisel plough, disk, and no-till), and reported that 
pounded water entry were not affected by tillage but by row positions significantly. Water entry rate according to their results were found to be $86.5 \mathrm{mmh}-1$ in the row, $18.6 \mathrm{mmh}^{-1}$ in none tracked inter row, and $2.38 \mathrm{mmh}-1$ in the tracked inter row. By number the water entry in NT practice was faster but it was not significant.

The authors then attributed the preferential flow through biological and structural macro pores observed to be faster infiltration times in the no-till. A field study was conducted in simulated rainfall $(65 \mathrm{mmh}-1$ for $1 \mathrm{hr})$ on a bare and residue covered soil by Baurnhardt and Lascano (1996) showed on bare soil lowest cumulative infiltration value of $28.7 \mathrm{~mm} / \mathrm{h}$. The infiltration rate was observed to have increased curvilinear with increase in surface residue. Akgul and $\mathrm{Ba}$-ayi-it (2005) worked on soil depth and observed that at $60 \mathrm{~cm}$ depth the soil texture becomes rougher and this particular depth is not affected by TM and soil moisture constant.

The studies of Aboudrare et al. (2006), showed statistically significant soil TM effect on soil $\mathrm{H}_{2} \mathrm{O}$ content. Chaudhary et al. (1992) compared CT method to conversation till and no-tillage methods and reported water conservation and economic returns of $13 \%$ on notill. Increased surface accumulation of residues according to Grant et al. (1997) may reduce exchange materials between the soil surface and the atmosphere such as gas and energy exchange. Tillage effect on several parameters such as soil temperature, aeration and water regimes have been documented by Licht and Al-Kaisi (2005). In a study conducted to compare water storage in no-till and CT, Franzluebbers et al. (1995b) observed that $\mathrm{H}_{2} \mathrm{O}$ storage in no-till was higher compared to conventional till during sorghum/wheat/sorghum production but at soil deeper depths equal or higher value of water storage in conventional till was recorded. They equally observed that soil heat was least in no-till compare to conventional till and BD was higher in no-till relative to conventional till. Grant et al. (1997) reported similar results using mathematical model, ecosystem, with elevated $\mathrm{CO}_{2}$.

When the root of crops are rooted and developed, penetration resistance of soil become irrelevance. If plant roots are not able to penetrate deeper into the soil it means critical soil penetration resistance limit, this however depends on crops grown and soil texture. Some authors found this limit to be 3.6 others - 2.0. Experiment conducted at LIA in Dotnuva by Cesevicius et al. (2005) reported positive relationship between $\mathrm{BD}$, yield of barley and penetration resistance of soil. That soil air circulation with the interaction of penetration resistance affects the yield of crop indirectly. The field experiment conducted between 1997 to1999 by Stancevicius et al. (2003) in light loam lying on sandy loam tillage effects did not change significantly soil bulk density and moisture at different barley crop growth stages. When soil is directly drilled, it picks up water gradually and in arid state the water is stored in plough layer. Sakar et al. (2007) stated that in kind situation the use of soil water become more efficient in soil conventionally tilled.
Studies in Lavia conducted by Ausmane et al. (2004) on a heavy loam soil with barley and barley under sown to clover and timothy recorded $27.1 \%$ reduction in barley and $8.3 \%$ in timothy.

\section{Effect of Tillage on Stability and Aggregation of Soils}

Brady and Weil (2002) observed soonest after ploughing, TP increased, however tillage operations increased OM oxidation and reduce stability of aggregates when practiced for a long time in piece of land. Tillage effect on long-time study on soil quality on continuous maize was estimated using indicators such as $\mathrm{BD}$ and water stable aggregates by Karlen et al. (1994). Their result findings showed that plots under notill for 12 years had higher total carbon, stable surface soil aggregates and microbial activity. In another experiment, increased surface residue was found by the authors to be linked with an increase in water stable aggregates. Rhoton (2000) after 4 years study recorded increased aggregate stability in no-till due to higher content of OM.

The conservation tillage increased infiltration of water and storage efficiency hence reduction in soil loss from wind or water erosion, improve water and air quality, increase wild life (Mc Laughlin and Minease 1995). Temperature, climate and soil conditions greatly influence the adoption of conservation tillage. Lal and Shukla (2004) observed that in coming $\mathrm{H}_{2} \mathrm{O}$ permeate soil when the pores become saturated, the excess water will run off or pond on the soil surface. Lampurianes and Cantero-Martinez (2006) found out that infiltration rates of no-till soils were higher than the CT soils due to soil organic matter retention, more macro pores and earthworm activity. Although due to higher soil BD in notill and large initial soil pores in tilled soils, decreased infiltration rates are observed in NT compared to CT methods. According to Moreno et al. (1997) on sandy clay loam soil conventional tillage practices will always have significantly higher infiltration rate than conservation tillage methods. Hydraulic conductivity because of its spatial and variability nature as it were is usually not an ideal indicator for soil management systems. The presence of connected macro pores has equally been found to affect early water absorption rates in drought soils and saturated hydraulic conductivity .This scenario may result from biological activity. In order to understand the relationship between hydraulic properties and macro pore structure under different tillage-residue Trojan and Linden (1998) argued the system is very important in earthworm affected soils for the nature of solutes and water flow to be understood. In an effort to address the flow characteristics taken into cognisance the benefits of interaction between the activity of soil organisms, hydraulic properties of soil and management system in use, because SHC and sorptivity have shown to be difficult to estimate from water infiltration tests in a field trials. Broad assessments of Ks properties are important in order to strike a balance 
between the impact of soil management system and variability for statistical significant reasons. DarcyBuckingham flux-gradient approach was used by Falleiros et al. (1998) to estimate $\mathrm{H}_{2} \mathrm{O}$ flow in soil, but did not quantify variability in soil properties in field-scale. Nonetheless to overcome the problem enhanced infiltration equation was derived by Ali and Swartzendruber (1994) to overcome negative computations of $\mathrm{Ks}$ values and in detecting variations in crop management practices. The authors from derived equation observed that statistical significant differences among crop rotations, where the largest values of Ks was found were sorghum was planted and the smallest Ks values were found with soybean.

Logsdon et al. (1990) measured the saturated hydraulic conductivity in undisturbed cores taken from upper Midwest soils and found mixed results. The data shows considerable variation between sites. For example the Rozelta soil (Lancaster, WI) had greater flow in the no-till soil at both depths, while the ploughed soil had much greater conductivity at both depths in the Waukegan soil (Rosemount, MN).

Conservation tilled soils generally had more plant available water, which could be important to a crop in times of moisture stress (Datiri and Lowery 1991b).

\section{Effect of Tillage on Hydraulic Conductivity}

Hydraulic conductivity is saturated and unsaturated processes in soils. Hydraulic processes highly influenced management systems and biological activities such as crop roots and earthworms. It is estimated by soil texture and structure. Based on texture and depth of soil studied Azooz et al. (1996) observed that mixed results are reported on saturated hydraulic conductivity (Ksat). Hydraulic conductivity estimated from soil cores was found to change easily with surface soil in no-till versus mould board plough and chisel plough cores because of random occurrence of large bio pores from either earthworm burrowing and root channels (Logsdon et al., 1990). Starr (1990) compared plough-till and conservation tillage systems in a field infiltration trials and found out that for conservation tillage $\mathrm{K}$ sat was higher during the midseason (late July through August) compared to plough-till and no difference between the systems in early season (early June - mid-July) and after crop harvest. Raper et al., (2000) argued that a well planned tillage operation in cognisance to soil hydraulic temporal changes properties can provoke advantages in those localities hampered with poor yield and insufficient input in the past. Soil parent material, climate and management systems affect the dynamics and development of soil structural aggregation. Shrink/swell clays according to Horn et al. (1994) and Mc Garry et al. (2000) play major role in natural changes of soil architecture and soil hydraulic properties responses to soil management systems. Karibba et al. (2001), found that field hydraulic conductivity values showed significant differences and observed that fallow soil tilled with chisel plough showed higher values than disc plough. The interactive effects of treatments showed that maximum value of field saturated hydraulic conductivity $(2.98 \times 10-$ 4 CMS-1) was recorded when the farm yard manure (FYM) was applied at $40 \mathrm{mg}$ ha-1 in deep tillage against the minimum value (2.93 $\times 10-4$ CMS-1) in case of application of recommended NKP in minimum tillage.

Under NT the increased percentage of soil organic matter promote plant root development as well as fauna proliferation that enhance trench creation for air and water penetration (Osunbitan et al., 2005) and the continuity of these channels are then maintained due to the lack of soil disturbance. Osunbitan et al. (2005) found that the surface soil had a higher Ks under NT compared with $\mathrm{CT}$. The amount of water retained in the soil at a matrix potential of between 0 and $-1500 \mathrm{kPa}$ is a function of size group and is therefore influenced by the type and intensity of tillage. Under NT the improved aggregation and pore continuity allows the soil to receive more water due to better infiltration and higher hydraulic conductivity. In addition, NT soils lose less water through gas due to waste accumulation on the soil surface. Consequently, NT soils usually maintain a higher moisture content than soils which are ploughed (Fabrizzi et al., 2005; Bescansa et al., 2006). Furthermore, ploughing increases the number of macro pores and thus at saturation the volumetric water content, (or water-filled porosity; WFP), is greater than that under NT. However, macro pores drain quickly and the greater number of micro pores and meso pores under NT allow the soils to retain more moisture within the plant available range, thus the WFP at field capacity is greater under NT. Bescansa et al. (2006) attest that in $15 \mathrm{~cm}$ layer soil in semi-arid northern Spain the water retention at saturation was $13 \%$ greater under CT than NT but at $-33 \mathrm{kPa}$ the water retained was $11 \%$ lower under CT than NT.

As mentioned previously, soils which are continuously ploughed are more susceptible to compaction and may reach high bulk densities over time. If ploughed soils compact over time it is likely that micro pores constitute the majority of the total porosity and water is therefore held at lower matrix potentials making it less available to plants (Bescansa et al., 2006). When ploughed soils compact and are dominated by micro pores they often hold less moisture than NT soils within the plant available range and at saturation. NT soils are able to retain more moisture than ploughed soils which have compacted as macro pores are created by earthworm activity and meso pores are maintained due to better soil structure. Increased water retention under reduced tillage is a result of improved infiltration, reduced evaporation and protection of the soil surface from mechanical impact of precipitation (Fabrizzi et al.,2005). This has particular relevance in the semi-arid climate and water scarcities are limiting factors for crop production. Implementing conservation tillage practices can therefore improve yields and sustainability.

A large number of authors have documented many findings on water retention on agricultural soil and 
observed that increases in water retention can be achieved through the following;

i accumulation of plant wastes on the surface of soil this will reduce loss of $\mathrm{H}_{2} \mathrm{O}$ through gas and erosion (Blevins 1971; Azooz et al., 1996)

ii promote good soil architecture and network of pores this will enhance favourable aggregate formation.

Tillage especially at greater matrix potentials affects water retention (Hill 1990) of which Hillel (1998) found to range from 0 to $100 \mathrm{kPa}$. Statistical significant effect of plough till, no-till and matrix potential was recorded by Hill (1990). He observed that ploughed soils retained more water at higher potentials from range 0 to about -2 $\mathrm{kPa}$ and no-till soils retained more water under lower potentials that range from -3.9 to $-40 \mathrm{kPa}$. These result findings simple suggest that constant tillage increase the proportion of macro-pores that loose water very easily more than the micro and meso-pores, hence the capacity to hold water in the tillage zone decreased rapidly.

\section{Effect of Tillage on Water Relationship}

The kind of tillage method use in a field potentially influence water infiltration and soil $\mathrm{HC}$, while infiltration rate depend on factors like quantity of waste on soil surface, degree of crust and proportion of macro-pores. Waste accumulation decrease soil crusting through energy absorption from rain drop, this help to retain continuously macro-pores for efficient water infiltration in soil surface especially with regards to conservation tillage. Earthworm tunnels, $\mathrm{H}_{2} \mathrm{O}$ and root channels are sources of macro pores in soil. Crop rotation and tillage practices affect the populations of earthworm as Kladivko (1993) has shown below. The most affected by tillage operation is the Lumbricus terrestris that produce vertical tunnels and pull leaf fall into their zone in the soil. Earthworm promote infiltration rate, recycle plant chemical nutrients within their soil domains.

Unger (1992) observed tillage operations be large enough for its effect to be noticed on soil which results in poor water percolation as a result of non- stability of aggregates. Datiri and Lowery, (1991a) found that the wetting front moved fastest following large natural storm events in no-till and chisel, when compared to mould board or ridge-till suggesting more favourable porosity in the no-till and chisel systems. Similarly, Ankeny et al. (1990) found that infiltration rate was increased in chisel plough in the un-trafficked portion of the field against NT but result changed where trafficked. Because of the temporal effect, it is critical to identify the antecedent conditions when infiltration is measured. Logsdon et al. (1993) found that infiltration rate will also be affected by seasonal effects, not just residue management, making a onetime measurement risky. They found greater variation in infiltration rates between measurement times than they did between tillage systems. They concluded that infiltration was dependent upon the formation of a crust, which they found to be affected by storms with high rainfall intensity, and partially ameliorated drying periods which induced cracking.
Tillage effect on Bulk density; Porosity; Soil structure, Pore size distribution

Degraded soils according to Raymond and Roy (1992); Chu and Bradshaw (1996) are of limited OM storage, high bulk densities, efficient rooting depth, compaction and subsoil exposed. These soils in their opinion can be reclaimed through enrichment with wastes like house hold waste and farm yard waste and mineral fertilizers. However they did mention that good understanding on the ability of the wastes to produce desired result when used in degraded soils is required. The works on tillage methods and organic wastes amendment by Stamatiadis et al. (1997) and Wilson et al. (2000) have shown improvement in soil conditions. The mechanized tillage according to Ohu et al. (1994) lead to destruction of soil aggregates. Eaton (2001) observed application of animal wastes and mineral fertilizer enhanced physicochemical properties of soil probably as a result of increased plant nutrients from the wastes. Lal (1997) reported that ploughing at $20 \mathrm{~cm}$ plus harrowing produced lower soil BD and high TP was as a result of loosening effects of tillage. While the work of Agbede (2006) showed that soil $\mathrm{BD}$ from ploughing at 10 and $20 \mathrm{~cm}$ soil depth in addition to harrowing lower macro-porosity and evaporation rate and effects of implement passes.

The favourable pore size distribution and SOM content in untilled versus tilled soils was attributed by Bescansa et al. (2006) to be responsible for the improvement in plant available soil water content and higher yields recorded. Weber (1990) reported that consequent to continuous CT system soils are increasingly threatened to physical decline these dangers spell debilitation, deterioration and destruction of soil productivity, if their changes are not detected early and controlled. The study of Reddy et al. (2007) showed that conventionally tilled soils released $37 \%$ greater $\mathrm{CO}_{2}$ efflux than no-till soils. This they found to represent greater carbon storage in no-tillage soils. Tillage activities have been found to cause bulk density exhibit seasonal variations. Franzluebbers et al. (1995) conducted a 2 season's experiment that involves determinations of 57 bulk density. They were able to found out that conventional tillage show much variation in bulk density versus no-till and annual estimate of conventional till were observed to be much less than values of no-till. Their result incompatibility was much felt in $5-12.5 \mathrm{~cm}$ depth soonest after tillage operations. The authors then argued that soil BD of conventional till reduced by tillage effect, but within short period match up with no-till level by densification.

\section{Effect of Tillage on Macro Porosity}

Macro pores are soil pores of which diameters range in millimetres to centimetres. They are major route for $\mathrm{H}_{2} \mathrm{O}$ infiltration and drainage. Shipitalo et al. (2000) found out that in medium and fine-textured soils water is moved by macro pores. While the study of Azevedo et al. (1998) showed that $70 \%-80 \%$ of molecules flowing per unit 
area of soil surface passed through macro pores. Tillage effects significantly altered macro porosity. Under no-till and CT dominant processes of macro pore formation are different. The reorganization of the solid component by the tillage materials under CT formed macro pores. These macro pores according to Mapa et al. (1986) are firm because of; precipitation effect; fall of the main soil constituent on its own hence the number and size of macro pores decreased; changes in the force of $\mathrm{H}_{2} \mathrm{O}$ molecules passing through the main soil pores.

In no-till soils, macro pores are merely formed from earthworm activity of decayed plant root channels and animal burrowing as reported by Wu et al. (1992). The total porosity for no-till soils is always less than the tilled soils. However, the continuity of the pores is much higher in no-till soils as reported by Roseberg and McCoy (1992). A large volume of water was found by Trojan and Linden (1998) to have infiltrated through macro pores channels made by earthworm accumulate in the deeper soil depth. The authors found the $\mathrm{H}_{2} \mathrm{O}$ not able to be estimated in a permeability assessment. It is important to note that water movement in macro pore done by passing the soil matrix is always a worthy agent in different types of soil with regard to water infiltration study in steady state.

\section{Pore Size Distributions}

Soil hydrology is influenced by pore size distribution. Size distribution is a major factor for water retention and hydraulic conductivity. The TP of different pore size classes of which are macro-, meso- and micro pores, however, researchers varied in sizes of macro pore 1000 $\mu \mathrm{m}$ or $750 \mu \mathrm{m}$ diameter were used as reported by Anderson et al. (1990). The next in the hierarchy is meso pores (10 to $1000 \mu \mathrm{m}$ effective diameters). Anderson et al. (1990) further classified meso pores into fine meso pores $10-50 \mu \mathrm{m}$ diameter and 50 to $1000 \mu \mathrm{m}$ coarse meso pores. Meso pores in contrast with water movement in macro pores allow water flow through main soil constituent without macro pores being filled up in soil profile. Micro pores $(>10 \mu \mathrm{m})$ which is the last category in the hierarchy correspond to that kind of flow in the main soil constituent moved by the pressure of the flow help to explain water movement in soil profile with regard to conduction and channelling.

Studies of Azooz et al. (1996); Hill (1990) and Benjamin (1993) noted that the size of coarse pores is higher in conventional till than in no-till soils while the fraction of small pores is higher in no-till soils. This they attributed to increased fraction of macro pores, hence TP is naturally higher in conventional till compared with no-till. Benjamin (1993) observed that soil size > $300 \mu \mathrm{m}$ in diameter in $10 \mathrm{~cm}$ soil surface was higher in chisel plough and mould board plough methods versus no-till methods for two silt loam soils. Generally cultivated soils have less $\mathrm{H}_{2} \mathrm{O}$ storage ability compare to soils of no-till, while soil fractions in no-till, show more favourable in soil water storage. Tillage influences the total porosity and soil fractions by affecting the architecture of the soil. This results in dynamics of soil hydraulic processes and soil strength, which are major determinants in the quality of soil. Due to its relationship with soil porosity, bulk density is a useful measure for assessing tillage effects on the architectural properties of the soil, and the consequent effects on the water and aeration status of the soil, hydraulic conductivity, infiltration rate, water retention characteristics, and soil strength. Generally, converting from a CT system to a conservation tillage system results in a higher BD and a lower total porosity (Fabrizzi et al., 2005) as macro pores are not created as is the case during ploughing (Bescansa et al., 2006). Osunbitan et al. (2005) compared BD in surface $5 \mathrm{~cm}$ of a NT soil with soils ploughed at three different tillage intensities. They concluded that the BD of the NT soil was significantly higher than other tillage treatments directly after tillage. However, the percentage increase in BD eight weeks after tillage was lowest under NT as natural resettlement of particles into a more compact arrangement is greater for the more intensive tillage treatments

Similarly, the study by Fabrizzi et al. (2005) shows that under NT less total porosity and higher BD were significantly recorded compare to conventional till up to $18 \mathrm{~cm}$ soil depth in the first two years after CT have been converted to no-till. However, in third year the BD under NT had decreased and was attributed to the re-establishment of the inherent soil structure. Increased susceptibility to soil compaction under CT compared to NT can result in similar bulk densities between CT and NT. Azooz et al. (1996) and Ishaq et al. (2002) observed little change in BD between tillage treatments and attributed this to the long delay between the tillage event and sampling which allowed the CT soil sufficient time to naturally consolidate and compact. Over time the BD under NT is lowered by the development of soil pores created by earthworm activity and root growth (Bescansa et al., 2006).

\section{Soil horizon, Bulk density and Porosity}

Soil tillage due to its effect on soil characteristics and plant yield is an observed technical operation in agricultural production.

The study of Buschiazzo et al. (1998) indicated that soils in humid climate regions and loamy soil surfer much physical wise from tillage impact compared to sandy soils and arid climates. Soil physical properties according to Lal (1991) should be kept optimal because of influences on the soil body. Soil with large bulk density value of the sub-plough layer poor water infiltration and transmission are characterized by decreased root growth and development, leading to decreased yield (Versa et al., 1997). Sandy loam due to its good aeration and porosity permit free water movement within the profile.

Soil compaction is a major determinant in physical properties of soil because of its role in increasing water run-off, erosion, decreased crop yield, poor infiltration and drainage result from its direct impact 
in the hydraulic conductivity processes of a soil. It was widely attested by authors that increasing the depth of tillage operations reduced the bulk density of soils (Schuler 1991; Evbach et al., 1992) however in a shallow soil depth tillage practices Alamouti and Navabzadeh (2007) reported higher soil bulk density. The most important attributes of physical status soil is its bulk density. This varies with depth, years and depth of particular tillage system. Total porosity by Mistina and Kovac (1993) is decreased much by higher bulk density and air capacity to water capacity ratio is changed favourable to $\mathrm{H}_{2} \mathrm{O}$ holding capacity.

Soil bulk density above $1.50 \mathrm{mgm}^{-3}$ in cultivated medium clay soils was reported by Lhotsky (1991), to have bad effect on crop development and yield and that TP below $45 \%$ on clay soils had negative effect on crop growth. The $1.50 \mathrm{mgm}^{-3} \mathrm{BD}$ value according to Butorac et al. (1992) is regarded as doorway or beginning. At a soil depth of $0-30 \mathrm{~mm}$ and $90-120 \mathrm{~mm}$ that is below the tillage zone Chang and Lind wall (1990) noted that among various tillage and crop rotations studied soil physical parameters did not differ significantly.

\section{CONCLUSION}

In determining the superiority of one management practice over the other soil types and their various reactions to tillage are ofparamount importance. However for the adoption of one practice over another, socio-economic considerations should betaken into account in decisionmaking. This is because in the past difficulties have arisen because limited information was given on soil types and characteristics when comparing onetillage treatment with another. In transfer of technology from one ecological zone or one soil type to the other there must be some cautions. Also some confusion with the practice regarded as no-tillage exists. There have been many incidences in which residues were removed while in some cases, surface soil wasmulched, or herbicides used to kill weeds in sites. Whereas in some cases comparison of management practices becomes not only difficult, conclusion drawn may not apply to similar agro-ecological conditions and soils.

\section{REFERENCES}

Abid, M. and Lal, R. (2008). Tillage and drainage impact on soil quality, I. Aggregate stability establishing carbon and nitrogen pools, Soil Till. Res. 100: 89-98.

Aboudrare, A, Debacke, P., Bouaziz, A. and Cheli, H. (2006). Effects of Soil Tillage and Fallow management on soil water storage and sun-flower production in a semi-arid Mediterranean climate, Agric. Water Management 53 (2006): 183-196.

Acharya, C.L. and Sharma, P.D. (1994). Tillage and mulching effects on soil physical environment, root growth, nutrient uptake and yield of maize and wheat on Alfisol in Northwest India. Soil Tillage Research, 32:291-302.

Acosta-Martinez, V., Klose, S., and Zobeck, T. M., (2003). Enzyme activities in semi-arid soils under conservation reserve program, native rangeland and cropland. J. Plant Nutr. Soil Soc. 166:699707.

Action, D.F. and Gregorich, L.J. (1995). The health of our soils: Toward sustainable agriculture in Canada, Agriculture and Agricultural food, Canada, CDR, 960 Carlingn.

Adamavicience, A., Romaneckas, K., Sarauskis, E. and Pilipavicus, V (2009). Non-chemical weed control in sugar beet crop under an intensive and conservation soil tillage pattern: 11 Crop productivity, Agronomy Res. 7:143-148.

Adamu, S. and Abdulrazaq, H. (2004). Effect of tillage on the growth and yield of groundnut (Arachis hypogea) at Bauchi in the Northern guinea savanna zone of Nigeria. International journal of food and Agricultural Research, vol. 1 (1-2); 4853.

Adamu, S. and Ezeaku, C.A. (2002). Effect of tillage on the growth and yield of cowpea (Vigna unquiculata) ( $L$ Walp) at Bauchi in the northern guinea savannah zone of Nigeria. Journal of Applied Sciences. Vol. 5(2): 2776-2785.

Adekiya, A.O., Agbede, T.M. and Ojomo A.O. (2009). Effect of tillage methods and soil properties, nutrient content; growth and yield of tomato on an alfisol of southwestern Nigeria. American-EuroAsian J. Sust. Agric. 3(3): 348-353.

Adeoti, S.S. and Olarewaju, J.D. (1990). Influence of manual and tractor drawn tillage tools on soil properties and tomato yield. AMA Agric. Mechanization in Asia, Africa and Latin America 21: 13-16.

Agbede, F.M., Ojeniyi, S.O. and Awodun, M.M (2008). Effect of tillage methods on growth grain yield. Northeastern Thailand J. 34:197-200.

Agbede, T.M. (2006). Tillage effect on cowpea (Vigna Unguiculata L.Walp) Production and some soil properties in southwest Nigeria. Journal of Research in Agriculture 2(1): 40-45.

Agbede, T.M. (2010). Tillage and fertilizer effects on some soil properties, leaf nutrient concentrations, growth and sweet potato yield on an Alfilsol in southwestern Nigeria. Soil and Tillage research, 110(1): 25-32.

Ahmed, N., Rashidi, M. and Vaes, A.G. (1996). Fertilizer and their use in Pakistan, NFDC, pub, No 4196 2nd edition. Pp274 Islamabad.

Ahn, P.M. and Hintze, B. (1990). No tillage, minimum tillage, and their influence on soil properties, In: Organic-matter management and tillage in humid and sub-humid Africa. Pp 341-349. IBSRAM proceedings No. 10. Bangkok: IBSRAM.

Ahuja, L.R., Fielder, F.; Dunn, G.H.; Benjamin, J.G. and Garrison, A. (1998). Changes in soil water 
retention curves due to tillage and neural reconsolidation. Soil Sci. Soc. Am. J. 62(5): 12281233.

Aina, P. O., Lal, R., and Roose, E.J. (1991). Tillage methods and soil and water conservation in West Africa. Soil and tillage Research 20:165-186.

Ajwa, H., Dell, C., and Rice, C., (1999). Changes in enzyme activities and microbial biomass of tall grass prairie soil as related to burning and nitrogen fertilization. Soil Bio. Boichem. 31:769777.

Akgul, M. and Ba-ayi-it, L. (2005). Detailed soil survey and mapping of Suleyman Demirel University farming land. Suleyman Demirel University J. Natural Appl. Sci. 9-3: 54-63.

Alamouth, M. Y. and Navabzadeh, M. (2007). Investigating of plowing depth effect on some soil physical properties. Pakistan Journal of Biological Sciences, 10:4510-4514.

Alani, L.W., Dou, F. and Hons, F.M. (2007). Soil organic $\mathrm{C}$ and $\mathrm{N}$ distribution for wheat cropping systems after 20 years of conservation tillage in central Texas, Agric, ecosystem Environment, 121:376-382.

Albuquerque, A., Sange, I. and Gnder, M. (2001) Modification of the soil physical properties and maize parameters including cropping and grazing under two tillage systems. Revista-Braseilera-deCincia-Do-solo, 25:717-23.

Al-Darby (1996). Conservation tillage. A comparison of methods. Agricultural Engineering 65(10):2432.

Alguacil, M.M., Lumini, E., Rodan, A., Salinas-Garcia, J.R., Bonfante, P. and Bianciotto, V. (2008). The impact of tillage practices on arbuscular mycorrhizal fungal diversity in subtropical crops: Ecol. Appl. 18:527-536.

Ali, A.S.I. and Swartzendruber, D. (1994). An infiltration equation to assess cropping effects on soil water infiltration. Soil Sci Soc. Am. J. 58(4): 1218-1223.

Aluko, O.B. and Lasisi, D. (2009). Effect of tillage methods on some properties of a tropical sandy loam soil under soybean cultivation. Proc. of 3rd international conference of WASAE and 9th international conference of NIAE, lle-ife, January, 25-29th, 2009, 162-174pp.

Alvaro-Fuentes, J. Lopez, M.V., Cantero-Martinez, C., and Arrue, J. (2008). Tillage effect on soil organic carbon practices in Mediterranean dry land agroecosystem Soil Sci. Soc. Am.J. 72:541-547.

Alvaro-Fuentes, J., Arrue, J.L, Cantero-Martinez, C. and Lopez, M.V. (2008). Aggregate breakdown during tillage in a Mediterranean loamy soil. Soil Till. Res. 101: 62-68.

Alvarze Z, R., Diaz, R.A., Barbero, N., Santanatoglia, O.J., and Blotta, L., (1995). Soil organic carbon, microbial biomass and $\mathrm{CO}_{2}-\mathrm{C}$ production from three tillage systems. Soil Tillage Research 33:1728.
Alvarze, R. and Steinback, H.S. (2009). A review of the effects of tillage systems on some soil physical properties, water content, Nitrate availability and crop yields in the Argentine Pampas, Soil Tillage Res. 104(2009): 1-15.

Am-Eurasion, J. (2009). Determination of yield component. Sustain. Agric 3(3): 348-353.

Anabi, M., Houot, S., Francou, C., Poitrenandi, M., and Bissonnias, Y.L. (2007). Soil aggregate stability improvement with urban compost of different maturities. Soil Soc. Am. J. 71:413-423.

Anderson, S.H., Gantzer, GJ. And Brown, J.R. (1990). Soil physical properties after 100 years of continuous cultivation. J. Soil water Conserve. 45:117-121.

Andraski. B.J. and Lowery, B. (1992). Erosion effect on soil water storage, plant water uptake, and corn growth. Soil Sci. Soc. Am. J.56-1911-1919.

Andren, O., Kätterer, T. and Hyvönen, R. (2001). Projecting soil fauna influence on long-term soil carbon balances from faunal exclusion experiments. Applied soil ecol., 18:177-186.

Angers, D., Bissonette, N., Legera, A., and Samson, N., (1993). Microbial and biochemical changes induced by rotation and tillage in a soil under barely production. Can. J. Soil Sci. 73:39-50.

Angers, D.A. and Carter, M.R. (1996). Aggregation and organic matter storage in cool, humid agricultural soils p.193-211. In M.R. Carter and B.A. Steward (ed) structure and soil organic carbon storage in agricultural soils. CRC. Press, Lewis Publishers, Bocca Raton, FL.

Angers, D.A., Bolinder, M.A. Carter, M.R., Gregorich, E.G., Drury, C.F., Liang, B.C., Voroney, R.P. Simard, R.R., Donald, R.G. Beyaert, R.P. and Martel, J. (1997). Impact of tillage practices on organic carbon and nitrogen storage in cool, humid soils of eastern Canada. Soil Till. Res. 41:191-201.

Angula- Jaramilo, R. Vandervaere, J. P., Roulier, S., Thony, J. L., Gaudet, J. P., and Vauchin, M. (2000). Field measurement of soil surface hydraulic properties by disc and ring infiltrations: A review and recent development. Soil Till. Res. 55(1-2): 1-29.

Anikwe, M.A.N. Obi, M.E., and Agbim, N. N. (2003). Effect of crop and soil management practices on soil compatibility in maize and groundnut plots in a paleoustult in Southeastern, Nigeria. Plant and soils, 253:457-465.

Anikwe, M.A.N., Mbah. C.N., Ezeaku, P.I. and Onyia, V.N (2007). Tillage and plastic mulch effects on soil properties and growth and yield of cocoyam (colocosia esculenta) on an ultisol in southeastern Nigeria. Soil and Tillage Research 93:264-272.

Anken, T., Weisskopf, P., Zihlmann, U., Forrer, H., Jansa, J., and Perhacova, K., (2004). Long-term tillage systems effect under moist cool conditions in Switzerland. Soil Till. Res. 78:171-183. 
Ankeny, M.D., Kaspar, T.C., Horeton, R. (1990). Characterization of tillage and traffic effects on unconfined infiltration measurements Soil Sci. Soc. Am. J. 54(3): 837-840.

Antapa, P. L and Angen, T.V. (1990). Tillage practices and residue management in Tanzania, In: organic matter management and tillage in humid and subhumid Africa. Pp 49-57. IBSRAM Proceeding No. 10-Bangkok IBSRAM.

Aon, M.A., Sarena, D.E., Burgos, J.L. and Cortassa, S., (2001). Microbiological, chemical and physical properties of soils subjected to conventional or notill management: An assessment of their quality status. Soil Tillage Research 60:173-186.

Arriaga, F.J., and Lowery, B. (2003). Corn production on an eroded soil: effects of total rainfall and soil water storage. Soil and Tillage Res. 71:87-93

Arshad, M.A., Franzuebbers, A.J. and Azooz, R.H. (1999). Components of surface soil structure under conventional and no-tillage in North Western Canada. Soil Till. Res. 53:41 - 47.

Arshad, M.A., Gill, K.S. and Coy, G.R. (1994). Wheat yields and weed population as influenced by three tillage systems on a clay soil in temperate continental climate. Soil and Tillage Res. 28:227238

Ausmane, M., Liepins, J. and Melngalvis, I. (2004) Possibilities of soil tillage optimization vagos: Scientific articles of Lithuanian University of Agriculture volume 64 (17): 7-12.

Awodun, M.A. and Ojeniyi, S.O. (2002). Effects of tillage practice on nutrient availability and performance of Amaranthus (Amaranthus Candetus L.) proceedings of 36th conferences of Agric. Society of Nigeria pp 101-102.

Azevedo, A.S., Kanwar, R.S. and Horton, R. (1998). Effect of cultivation on hydraulic properties of an lowa soil using tension infiltrometers. Soil Sci: 163;22-29.

Azooz, R.H., Arshad, M.A. and Franzluebbers A.J. (1996). Pore size distribution and hydraulic conductivity affected by tillage in Northwestern Canada. Soil Sci. Soc. Am. J. 60:1197-1201.

Babalola, L. A. and Olaniyi, J.O. (1999). Effect of some management practices on the performance of tomato (Lycopersicon Esculentum) in proceeding 15th Hortson conference, Ibadan pp 101-103.

Balkcam, K.S, Reeves, D.W., Shaw, J.N., Burnnester, C. H. and Curtis, L.M., (2006). Cotton yield and fibre quality from irrigated tillage systems in the Tennessee Valley. Agronomy Journal, 98: 596602.

Balota, E.L., Filho, A.C., Andrade, D.S. and Dick, R.P. (2004). Long-term tillage and crop rotation effects on microbial biomass $\mathrm{C}$ and $\mathrm{N}$ mineralization in a Brazilian Oxisol. Soil till. Res. 77: 137-145.

Bastida, F., Moreno, J.L., Hernandez, T., and Garcia C., (2006). Microbial degradation index of soils in semi-arid climate. Soil Biol. Bochem. 38: 34633473.

Baumhardt, R.L. and Lascano, R.L. (1996). Rain infiltration as affected by wheat residue amount and distribution in ridged tillage, Soil Sci. Soc. Am. J. 60(6):1908-1913.

Bayer C., Marin-Neto, L., Mielniczuk, J., Pillon, C. N. and Sangoi, L., (2001). Change in soil organic matter fractions under subtropical no-till cropping systems. Soil Sci. Am. J. 65: 1473-1478.

Beare, M.H., Hu, S. Coleman, D.C. and Hendrix, P.C. (1997). Influences of Mycelia fungi on soil aggregation and No-Till spring crop rotations. Bio/Fertl. Soil: 37:15-24.

Becerra, A.G., Cabello, M., Zak, M.R. and Bartoloni, N. (2009). Arbuscular mycorrhizal on dominant plant species in Yungas Forest, Argentina. Mycologia, 101(5): 612-621.

Belvins, R.L. and Frye, W.W. (1993). Conservation Tillage: An Ecological Approach to soil management. Adv. Agron. 51:33-78.

Benites, J.R. (1997). Conservation tillage and sustainable agriculture in Latin America, north, south and central America and the west Indies, In'I meeting of RELOCO; 17-20 November 1997, Morelia, mexico, 20pp.

Benjamin, J.G. (1993). Tillage effect on near surface soil hydraulic properties. Soil Till. Res. 26(4):277288.

Bergstrom, D.W., Monreal, C.M., and King, D.J. (1998). Sensitivity of soil enzyme activities to conservation practices. Soil Sci. Soc. Am. J. 62:1286-1295.

Bescansa, P., Imaz, M.J., Vitro, L, Enrique, A. and Hoogmoed W.B. (2006). Soil water retention as affected by tillage and residue management in semi-arid Spain. Soil Till. Res. 87:19-27.

Bessam, F. and Marbet, R. (2003). Long-term changes in particulate organic matter under notillage systems in semi-arid soil of Morocco In: Soil and Tillage Research International Conference, 2003.

Beyaert, R.P., Schott, J.W., and White, P.H (2002). Tillage effects on corn production in a coarse textured soil in southern Ontario. Agron. J. 94:767-774.

Bhagat, R.M. (1990). Effect of tillage and residue management on hydrothermal regime, nutrient uptake and yield of wheat in a river deposit. Soil Till. Res. 17:315-326.

Bhagat, R.M. and Verma, T.S. (1991). Impact of rice straw management on soil physical properties and wheat yield. Soil Sci. 182:105-115.

Bhagat, R.M. Sharoma, P.K and Verma, T.S. (1994). Tillage and residue management effect on soil physical properties and rice yields in north western himdayan soils. Soil Tillage Res. 29: 323334.

Bhattacharyya, R., Kundu, S., Pandey, S.C., Singh, K.P. and Gupta, H.S., (2008). Tillage and irrigation 
effects on crop yields and soil properties under the rice-wheat system in the Indian Himalayas. Agric. Water Manage. 95:993-1002.

Birkas, M., Jolankai, M., Gyuricza, C. and Percze (2004). Tillage effects on compaction, earthworms and other soil quality indicators in Hungary. Soil Tillage Research 78: 185-196.

Bisht, R. Chaturvedi, S., Srivastava, R., Sharma, A.K. and John, B.N. (2009). Effect of arbuscular mycorrhizal fungi, pseudomona fluorescens and Rhizobium Leguminosarum on the growth and nutrient status of Dalbergia Sissoo Roxb. Tropical Ecology, 50(2): 231-242)

Blanco-Canqui, H., Gantzer, C.J., Anderson, S.H. and Alberts, E.E. (2004). Tillage and crop influences on physical properties for an Epiaqualf. Soil Sci. Soc. Am. J. 68:567-576.

Bolan, N., Andriano, D. and Mahimairaja, S. (2004). Distribution and bioavailability of trace elements in livestock and poultry manure products. Critical reviews. Environmental Sciences and Technology 34:29-338.

Bolinder, M.A.A., Augers, A., Gregorich, E.G. and Carter, M.R. (1998). The response of soil quality indicators to conservation management, Can. J. Soil Sci. 79:37-45.

Bonari, E., Mazzoncini, M., Silvestri, N., Pafiai, M, Barbafici, M. Borin, M. and Saltin, M. (1994). Effects of different soil tillage systems of soil physical characteristics and maize yield. Proceedings of the 3rd congress of the European society of Agronomy pp:454-5. Padova University, Abano-Padava, Italy 18-22 Sept. 1994.

Bonfil, D.J., Mufradi, L., Klitman, S., and Asido, S. (1999). Wheat grain yield and soil profile water distribution in a no-till arid environment. Agron. J. 91:368-373.

Boquet, Donald, Robert, J. Hutchinson, L., and Gary AC, Breitenbeck (2004). Long term tillage cover crop and Nitrogen rate effects on cotton: yield and fibre properties. Agronomy Journal, 96: 14361142.

Bordovsky, D., G., Chaudhary, M., and Gerard, C.J. (1998). Tillage effects on grain sorghum and wheat yields in the Texas rolling plain. Agron. J. 90:638-643.

Borie, F. Rubio, R., and Morales, A. (2000). Arbuscular mycorrhizal fungi and soil aggregation. J. Soil Sci. Plant Nutr. 8:9-18.

Borie, F., Rubio, R., Rouanet, J.L., Morales, A., Borie, G. and Rojas, C. (2006). Effects of tillage system on soil characteristics. Glomalin and mycorrhizal propagules in a Chilean ultisol. Soil Till. Res. 88:253-261.

Borresen, T. (1993). The long-term effect of tillage practices on soil properties and crop yield. Soil Tillage and Environment. The 228th seminar of NJF, Finland.

Bouman, O.T., Curtin, D., Campbell, C.A., Biederbeck, V.O. and Ukainetz, H. (1995). Soil acidification from long term use of anhydrous ammonia and urea Soil Sci. Soc. Am. J. 59:1488 - 1494.

Bowman, R.A. and Halvarson, A.d. (1998). Soil chemical changes after nine years of differential $\mathrm{N}$. fertilization in a no-till dry land wheat-cornfallow rotation. Soil Sci. 163:241-247.

Bradford, J.M. and Peterson, G.A. (2000). Conservation tillage. In: Summer, M.E (ed), Handbook of Soil Science. CRC press, Boca Raton, USA, pp247-270.

Brady, N.C. and Weil, R.R. (1999). Nature and properties of soil, I2th Edn Prentice-Hall, Inc. Pearson Education, upper saddle River, NJ, USA.

Brady, N.C. and Weil, R.R. (2002). Nature and properties of soils, 13th edn. Pearson Education, Inc., Upper saddle River, New Jersey, 960pp.

Brandt, S.A. (1992). Zero vs conventional tillage and their effects on crop yield and soil moisture. Can. J.Plant Sci. 72(3): 679-688.

Brown, G.G., Barois, I. and Lavelle, P. (2002). Regulation of soil matter dynamics and microbial activity in the drilosphere and the role of interations with other functional domains. Eur. J. Soil Biol. 36:177-198.

Bruce, R.R., Langdale, G.W., West, L.T. and Miller, W.P. (1995). Surface soil degradation and soil productivity restoration and maintenance. Soil Sci. Soc. Am. J. 59:654-660.

Buah, S.S.J. and Mwinkaara, S. (2009). Response of sorghum to nitrogen fertilizer and plant density in the Guinea Savannah Zone. J. Agron. 8:124-130.

Bunn, R. Lekberg, Y. and C. Zabinski (2009). Arbuscular mycorrhizal fungi ameliorate temperature stress in thermophilic plants. Ecology: 90(5): 1378-1388.

Buschiazzo, D.E. Panigatti, J.L. and Unger, P.W. (1998). Tillage effects on soil properties and crop production in the sub-humid and semi-arid Argentinean Pampas. Soil Tillage Research, 49: 105-116.

Butorac, A. Basic, F., Tursic, I., and Mesic, M. (1992). The response of some field crops to soil compaction. Proc. Int. Conf. Soil compaction and soil management. Tallin: 276-285.

Calderon, F., J., Jackson, L.E., Scow, K.M. and Rolston, D.E. (2000). Microbial responses to stimulated tillage in cultivated and uncultivated soils. Soil Boil. Biochem. 32:1547-1559.

Calvino, P.A. (1998). Estudio del aqua en el suelo durante el ciclo del cultivo de maiz, bajo labranza convencional y siembra directa monografia de Especialista. (Universidad nacional de Mardel Plata Mardel Plata City (1991 pp.519, 707).

Cambardella, C.A. and Elliott, E.T. (1992). Particulate soil organic matter changes across a grassland cultivation sequence. Soil Sci. Soc. Am. J. 56:777783.

Cambardella, C.A. and Elliott, E.T. (1993). Carbon and nitrogen distribution in aggregates from 
cultivated and native grassland soils. Soil Sci. Soc. Am. 3.57:1071-1076.

Cambardella, C.A., Moorman, T.B., Andrew, S.S. and Karlen, D.I. (2004). Watershed scale assessment of soil quality in the loss hills of southwest lowa. Soil and Tillage Research; 78:237-247.

Campbell, C.A., Lafond, G.P., Zenter, R.P. and Biederbeck, V.O. (1991). Influence of fertilizer and straw bailing on soil organic matter in a thin black chernozem in western Canada. Soil Biol. Biochem. 23:443-446.

Campbell, C.A., McConkey, B.E., Biederbeck, V.O. Zenter, R.P. and Peru, M.R. (1998). Long-term effects of tillage and fallow-frequency on soil quality attribute in a clay in semi-arid southwestern saskatcharan. Soil Till. Res. 46: 135-144.

Caner, L.B., Dambrine, E., Ponge, J.F., Chauvat, M. and Lianque, C. (2006). Origin of the nitrogen assimilated by soil fauna living in decomposing beech litter. Soil Biol. Biochem. 36:1861-1872.

Carter, M.R. (1992). Influence of reduced tillage systems on organic matter microbial biomass, macro-aggregation distribution and structure stability of surface soil in the humid climate. Soil Tillage Research, 23: 361-372.

Carter, M.R. and Ivany, J.A. (2006). Weed seed bank composition under three long-term tillage regimes on a fine sandy loam in Atlantic Canada. Soil Till. Res. 90:29-38.

Carter, M.R. and Stewart, B.A. (1996). Structure and organic matter storage in agricultural soils. Advances in soil science. CRC Press, Boca Raton, FL. PR 182-245.

Carter, M.R., Saderson, J.B., Ivany, J.A. and White, R.P. (2002). Influence of rotation and tillage on forage maize productivity, weed species and soil of a fine sandy loam in the humid climate of Atlantic, Canada. Soil and Tillage Research, 67:85-98.

Castilo, C., Rubio, R., Rouanet, J.L. and Borie, F. (2006). Early effects of tillage and crop rotation on arbuscular mycorrhizal fungal propagules in an ultisol. Biol. Fertile. Soils 43: 83-92.

Castro Filho, C., Lourenco, A., Guimaraes, M.D.F and Fonseca, I.C.B (2002). Aggregate stability under different soil management systems in a red latosol in the state of Parana, Brazil, Soil Till. Res. 65:4551.

Cesevicius, G., Feiza, V. and Feiziene, D. (2005). The effects of soil tillage systems of various intensity and plant residues on soil physical properties and barley yield. Vagos; Scientific articles of Lithuanian University of Agriculture, Vol. 69 (22):7:18 (in Lithuanian).

Cetin, M., Ozgoz, E., Gurham, R. (2005). The effect of different tillage systems on some physicomechanical properties of the soil at second crop Production University of Gazi Osmanpasa, J. Agric. Faculty, 22(1): 31-36.
Chan, K.Y. (2001), An overview of some tillage impacts on earthworm population abundance and diversity-implications for functioning in soils. Soil Tillage Res. 57:179-191.

Chang, C. and Lindwall, C.W. (1990). Comparison of the effect of long-term tillage and crop rotation on physical properties of a soil. Can. Agric. Eng. 32(1): 53-55.

Chase, C.A and Duffy, M.D. (1991). N economic analysis of the Nashua tillage study: 1978-1987. J. Prod. Agric. 4:91-98.

Chatterjae, A. and Lal, R. (2009). On farm assessment of tillage impact on soil carbon and associated soil quality parameters. Soil Tillage Res. 104.

Chaudhary, A.D., Javed, M., Rane, M.A., Sarwar, A. and Zaman, Q. (1992). Comparative performance of direct drilling and conventional tillage practices under rice-wheat rotation system. Pakistan J. Agric. Sci. 29:5-8.

Chen, Y.; Tessier, S., and Gallichand, J. (1998). Estimate of tillage effects on saturated hydraulic conductivity.Can. Agric. Eng. 40(3):169-177.

Chen, Ying, Tessier, S. and Irvine, B. (2004). Drill and crop performance as affected by different drill configurations for zero till seeding. Soil and Tillage Research, 77;147-155.

Chivenge, P.P., Musra, H.K, Giller K.E., Maptumo, P. and Sex., J. (2007). Long term impact of reduced tillage and residue management on soil carbon stabilization: implication for conservation Agriculture on contrasting soils, Soil Tillage Res. 94(2007); 328-337.

Christensen, B.T. (1996). Carbon in primary and secondary organo-mineral complexes p.97-166. In M.R. Carter and B.A. Stewart (ed). Structure and organic matter storage in agricultural soils. CRC press, Lewis Publishers, Boca Raton, FL.

Chu, C.M. and Bradshaw, A.D. (1996). The value of pulverized refuse fine (PRF) as a substitute for top soil in land reclamation Field Studies, J. Appl. Ecol. 33:851-857.

Ciotta, M.N., Bayer, C., Fontoura, S.M.V., Emani, P.R. and Albuguerque, J.A. (2003). Soil organic matter and cation exchange capacity increase in a low activity clay soil under no-tillage system. Cienc. Rural 33:1161 - 1164.

Clapperaton, M.L., Miller, J.J., Larney, F.J. and Lindwall, C.W. (1997). Earthworm populations as affected by long tillage practices in southern Albert-Canada. Soil Biol. Biochem. 29:631-633.

Collins, H.P., Elliot, E.T., Paustian, K., Bundy, L.G. Dick, W.A., Huggins, D.R., Smucker, A.J.M. and Paul, E.A. (2000). Soil carbon pools and fluxes in long-term corn belt agroecosystems. Soil Biol. Biochem. 32:152-168.

Cornejo P., Rubio, R. and Borie, F. (2009). Mycorrhizal propagule persistence in a succession of cereals in a disturbed and undisturbed andison 
fertilized with two nitrogen sources. Chilean J. Agric. Res. 69: 426-434.

Cresswell, H.P., Painter, D.J. and Cameroun, K.C. (1993). Tillage and water content effects on surface soil hydraulic properties and shortware albedo. Soil Sci. Soc. Am. J. 57(3): 816-824.

CTIC (2004). Conservation technology information centre. http://www.ctic.purdue.edu.

Dalal, R.C. (1992). Long-term trends in total nitrogen of a vertisol subjected in zero tillage, nitrogen application and stubble retention, Aust J., Soil Res. 30:223-231.

Dao, T.H. (1993). Tillage and winter wheat reduce management effects on water infiltration and storage. Soil Sci. Soc. Am. J. 57:1586-1595.

Dao, T.H. (1996). Tillage system and crop residue effects on surface compaction of a pakustoll. Agron J. 88(2): 141-148.

Datiri, B.C. and Lowery, B. (1991a). Tillage effects on rain-generated wetting from migration through a Grisworld silt loam soil. Soil Tillage Research, 21:243-256.

Datiri, B.C. and Lowery, B. (1991b). Effects of conservation tillage on hydraulic properties of a Grisworld silt loam soil. Soil Tillage Res. 21:257271.

Denef, K.J., Six, J., Merks, R. and Paustian, K. (2004). Carbon sequestration in micro-aggregate. Soil Sci. Soc. Am. J. 68:1935-1994.

Derpsche, R. (1999). Frontiers in conservation agriculture and advance in conservation practice, May 28th West Lafayette, U.S.A

Desjardins, T. Charpentier, F., Pashanasi, B., PandoBahuon, A., Lavelle, P. and Mariotti, A. (2003). Effects of earthworm inoculation on soil organic matter dynamics of cultivated ultisol. Pedobiologia, 47: 835-841.

Diaz-Zorita, M. (2000). Effects of deep tillage and nitrogen fertilization interactions on dry land corn (Zea mays L) productivity. Soil and Tillage Research, 54:11-19.

Dick, R.P. (1994). Soil enzyme activities as indicator of soil quality. In: Doran. J.W. Coleman, D.C., Bezdicek, D.F., Stewart, B.A. (eds): Defining Soil quality for sustainable environment. Soil Sci. Soc. Am. Spec. Pub. 35 Madison, pp. 107-124.

Dick, W.A., McCoy, E.L., Edwards, W.M. and Lal, R. (1991). Continuous application of no-tillage to Ohio soils. Agron. J. 83:65-73.

Dickey E.C. and Siemens, J.C. (1992). Conservation tillage systems and management, First edition midwest plan service lowa State University, lowa USA.

Do-an, T., Bilgehan, G.A. and Yalcin (2000). The effect of different stalk tillage and seed bed preparation methods in cotton farming upon some physical characteristics and aggregate stability of the soil. Proceedings of international symposium on desertification 1.3-17 June, 2000, Konya Turkey.
Domitruck, D. and Crabtree (ed), (1997). Zero tillage advancing the art Manitoba-North Dakota. Zero tillage farmers association, Minit, ND.

Donigan, A.S. Pawardhan, A.S., Chinnaswamy, R.V., and Barnwell, T.O. (1997). Modeling soil carbon and agricultural practices in the central US: An update of preliminary study results pp499-518. In: R. Lal., J.M. Kimble, R.F. Follett and B.A. Stewart (eds). Soil processes and carbon cycle. CRC. Press. Boca Raton, FL.

Driver, J.D. Holben, W.E. and Rillig, M.C. (2005). Characterization of glomalin as a hyphal wall component of arbuscular mycorrhizal fungi. Soil Biol. Biochem. 37: 101-106.

Eaton W.D. (2001). Microbial and nutrient activity in soils of Ghana under different tillage systems. Appl. Soil Biol. Biochem, 8:19-24.

ECAT (2004). European conservation Agriculture organization. http://www.ecaf.org.

Egamberdiev, O. (2007). Changes of soil characteristics under the unflucenc of resource saving and soil prospective technologies within the irrigated meadow alluvial soil of the Khorezm region, Ph.D. thesis. National University of Uzbekistan (in Uzbek).

Eigenbrod, K.D. (2003). Self-healing in Fractured finegrained soils. Can. Geotech. J. 40(2): 435-419

Espana, M. B., Rdriguez, M. Cabrera, I.B.E. and Cercanti; B. (2002). Enzymatic activities and contribution of corn residues to soil nitrogen under tillage practices in the central plains. Venesuela Terra, 20: 81-86.

Fabrizzi, K.P., Garcia, F.O., Costa, J.I. and Picone, L.I. (2006). Soil water dynamics, physical properties and corn and wheat responses to minimum and notillage systems in the southern pampas of Argentina, soil and Tillage Research, 81:57 - 69.

Fahong, W., Xuging, W. and Sayre, K.D. (2004). Comparison of conventional, flood irrigated, flat planted with furrow irrigated, raised bed planting for winter wheat in China, Field Crop Research 87: 35-42.

Falleiros, M.C. Portezan, O., Oliveira, J.C.M, Bacchi, O.O.S. and Reichardt, K. (1998). Spatial and temporal variability of soil hydraulic conductivity in relation to soil water distribution, using an exponential model. Soil Tillage Research, 45(3-4): 279-285.

Feddermann, N., Finlay, R., Boiler, T. and Elfstrand, M. (2010). Functional diversity in arbuscular myucorrhiza the role of gene expression, phosphorous nutrition and symbiotic efficiency. Fungal Ecology 3: 1-8.

Feng, Y., Motta, A.C., Reeves, D.W., Burmester, C.H. Santen, E.V. and Osborne, J.A. (2003). Soil microbial communities under conventional-till and no-till continuous cotton systems. Soil Biol. Biochem. 35: 1693-1703.

Ferrevas, L.A., Costa, J.L., Garcia, F.O. and Pecorain, C. (2002). Effect of no-tillage or some physical 
properties of structural degraded pertiocaleie, paleudoll of southern pampa of Argentina. Soil and Tillage Research, 54: 31-39.

Fisher, R.A. Santiveri, F., and Vidal, I.R. (2002). Crop rotation and crop residue management for wheat and maize in the sub-humid tropical highlands. 11 . Maize and system performance. Field Crops Research 79;123-137.

Fitter, A.H., Heinemeyer, A., and Staddon, P.L. (2000). The impact of elevated $\mathrm{CO}_{2}$ and global climate change on arbuscular mycorrhizas: A mycocentric approach. New phytol. 147:179-187.

Follett, R.F., Paul, E.A., Leavitt, S.W., Halvorson, A., Lyon, D.J. and Peterson, G.A. (1997). Carbon isotope ratios of great plains soils and in wheatfallow systems, Soil Sci. Soc. Am. J. 61: 10681077.

Food and Agricultural Organization (2001). Conventional ploughing erodes the soil-zero tillage is an environmentally friendly alternative, Madrid, Spain, October 2001.

Food and Agricultural Organization (2006). Spotlight conservation agriculture. Agriculture and consumer protection Department Rome, Italy. http:/www.fao.org/ag/magazine/0110sp.htm.

Ford, J.H. and Hicks, D.R. (1992). Corn growth and yield in uneven emerging stands. J. Prod. Agric. 5: 185-188.

Franzluebbers, A.J and Arshad, M.A. (1997). Particulate organic carbon content and potential mineralization as affected by tillage and texture. Soil Sci. Soc. Am. J. 61; 1382-1386.

Franzluebbers, A.J. (1999). Potential carbon and nitrogen mineralization and microbial biomass from intact and increasingly disturbed soils of varying texture. Soil Bio. Biochem. 31: 1083-1090.

Franzluebbers, A.J. (2002). Soil organic matter stratification ratio as an indicator of soil quality, Soil and Tillage research 66:95- 106.

Franzluebbers, A.J., Hons, F.M. and Zuberer, (1995). Tillage and crop effects on seasonal dynamics of soil $\mathrm{CO}_{2}$ evolution, water content, temperature, and bulk density. Appl. Soil Ecol. 2:95-109.

Franzluebbers, A.J., Hons, F.M. and Zuberer, (1995b). Tillage and crop effects on seasonal dynamics of soil $\mathrm{CO}_{2}$ evolution, water content, temperature, and bulk density. Appl. Soil Ecol. 2:95-109.

Franzluebbers, A.J., Hons, F.M. and Zuberer, D.A. (1994). Long-term changes in soil carbon and nitrogen pools in wheat management systems. Soil Sci. Soc. Am. J. 58: 1639-1645.

Franzluebbers, A.J., Hons; F.M. and Zuberer, D.A. (1995a). soil organic carbon, microbial biomass and mineralizable carbon and nitrogen in sorghum management system. Soil Sci. Soc. Am. J. 59: 460-466.

Frey, S.D., Elliot, E.T. and Paustian, K. (1999). Bacterial and fungal abundance and biomass in conventional and no-tillage agro-ecosystems along two climate gradients. Soil Biol. Biochem. 31: 573-583.

Fuentes, J.P., Flury, M. and Bezdicek, D.F. (2004) Hydraulic properties in a silt loam soil under natural prairie, conventional till, and no-till. Soil Sci. Soc. Am. J. 68:1679-1688.

Gadkar, V., Driver, J.D. and Rillig, M.C. (2006). A novel in vitro cultivation system to produce and isolate soluble factors released form hyphae of arbuscular mycorrhizal fungi. Biotechnol. Lett. 28: 1071-1076.

Galvez, L., Douds, D.D., Drinkwater, L.E. and Wagoner, P., (2001). Effect of tillage and farming system upon VAM fungus populations and mycorrhizas and nutrient uptake of maize, Plant Soil, 228: 299-308.

Gangwar, K.S., Singh, K.K., Shama, S.K. and Tomar O.K. (2006). Alternative tillage and crop residue management in wheat after rice in sandy loam soils of Indo-Gangetic plains. Soil and Tillage Research, 88(1-2): 242-252.

Ganjri, P.R., Arora, V.K, and Prihar, S.S. (2002). Tillage for sustainable cropping. Food product press; New York, USA.

Garcia, G., Roldan, A., and Hernandez, T., (1997). Changes in microbial activity after abandonment of cultivation in a semi-arid mediterranean environment. J. Environ. Qual. 26: 285-291.

Gebrezhler, A., Moua Zen, M., Handrik, V.B., Ramon, H. and Nyssen. J. (2006). Animal drawn tillage, the Ethiopian hard plough, Mareshaia reviewed, Soil Tillage Res. 59(2006): 129-143.

Germanas, L. and Bakasenas, A. (2004). Effect of crop sowing in various prepared stubble soil impared by straw. Research papers of IAg Eng Lu. A, vol. 36(4): 5-16. (In Lithuanian).

Gomez, E., Ferras, L., Toresani, S., Austitio, A., and Bizrro, V., (2001). Changes in some soil properties in a vertic Arguitdoll under short term conservation tillage. Soil Till. Research, 61:179186.

Govaerts, B., Sayre, K.D,, Ceballos Ramirez, J.M., Luna-guido, M.L., Limon-ortega, A., Deckers, J. and Dendooven, L. (2006). Conventionally tilled and permanently raised beds with different crop residue management effects on soil $\mathrm{C}$ and $\mathrm{N}$ dynamics. Biomedical and Life Sciences and Earth and Environmental Science; 280(1-2): 143155.

Govaerts, Bram, Ken D Sayre and Jozef Deckers (2005). Stable high yields with zero tillage and permanent bed planting. Field Crop Research, 94(1) 33-42.

Grant, R.F., Izaurralde, R.C., Nybora, M., Malhi. S.S. Solberg, E.D. and Hammermeister, D.J. (1997). Modeling tillage and surface residue effects on $\mathrm{C}$ storage under ambient vs elevated $\mathrm{CO}_{2}$ and Temperature in ecosystems, p 527-548. In R. Lal, J.M. Kimble, R.F Follet and B.A. Stewart (ed). Soil 
processes and the carbon cycle, CRC press Boca Raton, FL.

Gregorich, E.G. and Janzen, H.H. (1996). Storage of soil carbon in the high fraction and macro organic matter p167-190. In M.R. Carter and Stewart, B.A. (eds). Structure and organic mater storage in agricultural soils. CRC. Press Lewis publishers, Boca Raton, FL.

Gregorich, E.G., Carter, M.r., Angers, D.A., Monreal, C. M., and Ellert, H.H. (1994). Towards a minimum data set to assess soil organic matter quality in agricultural soils. Can. J. Soil Sci. 74: 367-385.

Gren, V.S., Stott D.E., Cruz, J.C., Curi, N., (2007). Tillage impact on soil biological activity and aggregation in a Brazilian Cerrada oxisol. Soil Till. Res. 92: 114-121.

Griffith, D.R. and Wollenhaupt, N.C. (1994). Crop residue management strategies for the Midwest. Adv. Soil Sci. pp 15-36.

Griffith, D.R., Mannering, J.V., Galloway, H.M., Parson, S.D. and Richey, C.B. (1993). Effect of eight tillage planting systems on soil temperature, percent stand, plant growth and yield of corn on five Indiana soils Agron. J. 65:321 - 326.

Gunapala, M. and Scow, K.M. (1998). Dynamics of soil microbial biomass and activities in conventional and organic farming systems. Soil Biol. Biochem. 30(6): 816.

Guo, Y.J. and Han, J.G., (2008). Soil biochemical properties and arbuscular mycorrhizal fungi as affected by afforestation of range lands in northern China. J. Arid Environ. 72: 1690-1697.

Gupta, Raj. Jat, M.L., Samor, S., Singh, V.P. and Sharma, R.K. 2006). Resource conserving technologies for rice production. Special issue on 2nd IRC 2006, Indian farming, pp42-45.

Guzha, A.C. (2004). Effects of tillage on soil microrelief, surface depression storage and soil water storage. Soil and Tillage Research 76:105114.

Halvorson, A.D., Reule, C.A. and Follett, R.F. (1999). Nitrogen fertilization effects on soil carbon and nitrogen in a dry land cropping system. Soil Sci. Soc. Am. J. 63: 912-917.

Hammad, E.A. and Dawelbeit, M.I (2001). Effect of tillage and field condition on soil physical properties, corn and sugar yield in vertisols of Kenana sugar Estate, Sudan, Soil Till. Res. 63(34).: 101-109.

Hamza, M.A. and Anderson, W.K. (2002). Improving soil physical fertility and crop yield on a clay soil in western Australia. Australian Journal of Agricultural Research, 53(5): 615-620.

Hamza, M.A. and Anderson, W.K. (2003). Responses of soil properties and grain yields deep gypsum application in a compacted loamy sand soil in Western Australia. Australian Journal of Agricultural Research, 54: 273-282.
Hamza, M.A. and Anderson, W.K. (2005). Soil compaction in cropping systems. A review of the Nature, causes and possible solution. Soil and Tillage Research 82(2): 121-145.

Hassink, J., Whitmore, A.P. and kubat, J. (1997). Size and density fractionation of soil organic matter and the physical capacity of soils to protect organic matter. Eur. J. Agron. 7: 187-199.

Heenan, D.P. and Taylor, A.C. (1995). Soil pH decline in relation to rotation, tillage, stubble retention and nitrogen fertilizer in S.E. Australia, Soil Use Manage. 11: 4-9.

Heenan, D.P., Chan, K. Y. and Knight, P.G. (2004). Long-term impact of rotation, tillage and stubble management on the loss of soil organic carbon and nitrogen from a chronic levisol. Soil Till. Res. 76:59-68.

Hemanz, J.L., Lopez, R., Navarrete, L., and SanchezGiron, V. (2002). Long-term effects of tillage systems and rotations on soil structural stability and organic carbon stratification in semi-arid central Spain. Soil and Tillage Research, 62; 4153.

Hemmat, A. and Taki, D. (2001). Grain yield of irrigated wheat as affected by stubble tillage management and seeding rates in central Iran. Soil and Tillage Res. 63; 57-64.

Hermawan, B. and Bomke, A.A. (1997). Effect of winter cover crops and successive spring tillage on soil aggregation. Soil Tillage Research, 44; 109-120.

Hill, R.L. (1990). long term conventional and no-tillage effects on selected soil physical properties. Soil Sci. Soc. Amer. J. 54; 161-166.

Hillel, D. (1998). Entry of water into soil In: environmental Soil Physics, Klute, A. (ed). Academic Press, San Diego, California, 771pp.

Horn, R. and Smucker, A. (2005). Structure formation and its consequences for gas and water transport in unsaturated arable and forest soils. Soil Till. Res. 82(1): 5-14.

Horn, R., Tauber, H. Wuttke, M. and Baumgartt, T. (1994). Soil physical properties related to soil structure. Soil Till. Res. 30(2-4): 187-216.

Horne, D.J. Ross, C.W., and Hughes, K.A. (1992). Ten years of maize, oats rotation under three tillage systems on a silt-loam soil in New Zealand. A comparison of some soil properties. Soil Till. Res. 22, 131-143.

Horne, D.J. Ross, C.W., and Hughes, K.A. (1992). Ten years of maize, oats rotation under three tillage systems on a silt-loam soil in New Zealand. A comparison of some soil properties. Soil Till. Res. 22, 131-143.

Hussain, I. Olson, K.R., and Ebelhar, S.A. (1999). Impacts of tillage and no-till on production of maize and soybean on an eroded Illinois silt loam soil. Soil Tillage Res. 53:37-49.

Igbal, M, Hassan, A.U., Ali, and Rizwanullah, M.(2005). Residual effect of tillage and farm 
manure on some soil, physical properties and growth of wheat (Tritticum aestivum L). Int.J. Agric. Environ. Biol. 1: 54 - 57.

I-ilder, A.A and Bayhan K. (2005). Tillage systems impacts upon seedbed properties and emergence of a dry land sumflower. Selcuk University J. Agric. Faculty, 19 (36); 120-124

Ishaq, M., Ibrahim, M. and Lal, R. (2002). Tillage effect on nutrient uptake by wheat and cotton as influenced by fertilizer rate Soil Till Res. 62:41 - 53 .

Ismail, I., Blevins, R.L. and Frye, W.W. (1994). Long term no - tillage effects on soil, Sci. Soc. Am. J. 58:193-198.

Izquierdo, I., Caravaca, F., Alguacil, M.M., and Roldan, A., (2003). Changes in physical and biological soil quality indicators in a tropical crop system (Havana, Cuba) in response to different agroecological management practices. Environ. Manage. 322; 639-645.

Jabro, J.D., Stevens, W.B., Iversen, W.M. and Evans, R.G. (2010). Tillage depth effects on soil physical properties, sugar beet yield, and sugar beet quality. Comm. Soil Sci. Plant Anal. 41: 908-916.

Jacobsen, J.S. and Westerman, R.L. (1991). Stratification of soil acidity derived from nitrogen Fertilization in winter wheat tillage systems. Commun. Soil Sci. plant Anal. 22: 1335-1346.

Jaiyeoba, I. A. (2003). Changes in soil properties due to continuous cultivation in Nigeria semi-arid savannah, Soil Till. Res. 70:91 - 98.

Jansa, J. Mozafar, A., Kuhn, G. Anken, T.,Ruh.R, Sanders, I.R. and Frossard, E. (2003). Soil tillage affects the community structure of mycorrhizal fungi in maize roots. Ecol. Appl. 13: 1164- 1176.

Jastrow, J .D. (1996). Soil aggregate formation and the accrual of particulate and mineral associated organic matter. Soil Biol. Biochem. 28: 665 - 676.

Jastrow, J .D. and Miller, R .M. (1997). Soil aggregate Stabilization and carbon sequestration: Feed backs through organic mineral associations p.207 - 223. In R. Lal, kimble, J. M; Follett, R . F. and Stewart, B.A. soil processes and the carbon cycle. CRC. Press Boca Raton, FL.

Jeffries, P., Gianinazzi, S., Perotto, S., Purnau, K. and Barea, J.M. (2003). The contribution of arbuscular mycorrhizal fungi in sustainable maintenance of plant health and soil fertility. Biol. Fertl. Soils 37: 1-16.

John, B., Yamashita, T., Ludwig, B and Flessa, H. (2005). Storage of organic carbon in aggregate and density fractions of silty soils under different types of land use. Geoderma 128: 63-79.

Jordhal, J.L and karlen, P.L. (1993). Comparison of alternative farming system-soil aggregate stability. Amer. J. Alt. Agric. 8: 27-33.

Josa, R. and Hereter, A.(2005). Effects of tillage systems in dry land farming on near surface water content the late winter period. Soil Till. Res. 82(2):173-183. Microbial processes and community structure to tillage and implications for soil quality, Geoderma, 114: 305-317.

Kabir, Z. (2005). Tillage or no-tillage: Impact on mycorrhoza. Can. J. Plant Sci: 85:23 - 29

Kabir, Z., O' Halloran, I.P., Tyles, J. W. and Hamel, C. (1997). Seasonal changes of arbuscular mycorrhizal fungi as a affected by tillage practices and fertilization: Hypa denik and mycarrhizal root colonization. Plant soil, 192:285 - 293.

Kabir, Z., O'Halloran, I.P., Widden, P., and Hamel, C., (1998). Vertical destruction of arbuscular my morrhizal fungi under corn (Zea mays L.) in no-till and conventional Tillage, systems. Mycorrhiza $8: 83-55$

Kanchikerimath, M. and singh, D. (2001). Soil organic matter and biological properties after 26 years for maize-wheat cowpea cropping as affected by manure and fertilization in a combisol in semi-arid region of India. Agriculture, Ecosystems and Environment 86(2): $155-162$.

Kandeler, E., Tscherko, D., and Spiegel, H., (1999). Long -term monitoring of microbial biomass, $\mathrm{N}$ mineralization and enzyme activities of a chemozem under different tillage management. Boil. Fertil. Soils 28:343- 351.

Kapusta, G., Krausz, R.F. and Matthews, J. L. (1996) Corn-yield is equal in conventional, reduced and no-tillage affer 20 years. Agron J. 88:812 - 817

Karibba, M., Hallaire, V. Curmi, P. and Lahmar, R., (2001). Effect of various cultivation method on structure and hydraulic prosperities of a soil on a semi and climate. Soil and Tillage Res. 60:43 - 53

Karlen, D. L., Wallenhaupt, n. C., Erbach, D. C., Berry E. C, Swan, J.B., Eash, N.S. and Fordahl, J,L (1994). Longterm Tillage effects on soil quality. Soil Tillage Research, 32: 313 - 327.

Karlen, D.L. and Stoott, D.E. (1994). A freme work for evaluating physical and chemical indicators of soil quality, 53 - 73. In: J.W. Doran et al, (eds) Defining Soil quality for a sustainable encironment, SSA special Publ. 35 SSSA Madison, WI.

Karlen, D.L., Andrew, S.S., and Doran, J.W. (2001), Soil quality: current concepts and applications. Adv. Agron. 74:1 - 40.

Kennedy, A. C. and Papendick, R.R. (1995). Microbial characteristics of soil quality, J. Soil Water Conservation 50:243 - 248.

Keshavarzpour, F. and Rashidi, M. (2008). Effect of different tillage methods on soil physical properties and crop field water melon (cibullus vilagaris). World Appl. Sci. J. 3: $359-364$.

Khan Khalid Mahmood (2002). Conservation technologies for sustainable cotton - wheat cropping system in Pakistan. International Workshop on conversation agriculture for sustainable wheat production in rotation with cotton in water-resource areas, $14-18$ October,, 2002 Tashkent, Uzbekistan. 
Khan, F.U.H., Tahir, A.R. and Yule, I.J. (2001). Intrinsic implication of different tillage practices on soil penetration resistance and crop growth. Int. J. Agric. Boil, 1:23 - 26

Kladivko, E.J. (1993). Earthworn and crop management. Agr. Guide, AY - 279. Purdue Univ. Coop. Ext., West Lafayette, InN.

Kombiok, J.M. Safo, E.Y. and Quansah, C. (2005). Yield and nitrogen fixation of cowpea as affected by tillage and cropping systems in the northern savanna zone of Ghana, West Africa J. Agric. Ecol., 7:95 - 108

Kouwenhoven, J.K., Perdok, U.D., Bor, J. and Oomen, G.J.M. (2002). Soil management by shallow mould boards ploughing in the Netherlands. Soil and Tillage Res. 46:125 - 139 .

Kovac, K. and Zak., S. (1999): Influence of various ways of soil cultivation on selected physical properties Ved. Prace, VURV Piestany, 29:13 - 22 (in Slovak)

Kreuzer, K. Bonkowski, M. Longel, R.. and Scheu, S. (2004). Decomposer animals (Lumbricidae, Collembola) and organic matter distribution affect the performance of Lolium perenne (Poaceae) and Trifolium repens (Fabacoae). Soil Biol. Biochem., 36:2005 - 2011.

Kurshid, K., Igbal, M., Arif, M.S. and Nawaz, A. (2006) Effect of tillage and mulch on soil, physical properties and growth of maize Int. J. Agric. Biol. 5:593 - 596.

Lafond, G.P., May, W.E., Steveson, F.C. and Derksen, D.A. (2006). Effects of tillage systems and rotations on crop production for a thin Black chemozem in the Canadian priries. Soil and Tillage Resarch, 89(2):232-245.

Lal, R (1991). Tillage and agricultural sustainable. Soil tillage Resarch, 20:133-146.

Lal, R. (1993). Soil erosion and conservation in West Africa, P.7 -26. In D. Pimentel (ed), world soil erosion and conservation. Int union for conservation of nature and natural resources, Switzerland

Lal, R. (1997). Long term tillage and maize mono culture effects on tropical Alfisol in western Nigeria 1 Soil Tillage Resarch, 42:145-160.

Lal, R. and Shukla, M.K. (2004). Principlies of Soil Physics. Marcel Dekker Inc, New York.

Lal, R., (1999). Soil management and restoration for C sequestration to mitigate the accelerated green house effect. Progr. Envt. Sci. 1:307-326.

Lal, R., Reicosky, D., and Hanson, J. (2007), Evolution of the plow over 10,000 years and the rational for no - till farming. Soil and Tillage Research, 93:1-12.

Lal, R.., Mahboubi, A.A., and Fausey, N.R (1994) Long-term tillage and rotation effects on properties of a central Ohio Soil. Soil Sci. Soc. Am. J. 58(2):517-522.

Lal., R. (2009). Laws of sustainable soil management Agron. Sustain. Dev., 29 (2009):7-9.
Lal; R: (1990). Tillage and crop production in the tropics. In: proc. Intl. symposium on applied soil physics in stress environment. 22-26th January, 1989, Islamabed, Pakistan.

Lampurlanes, J. and Cantero- Martinez (2006). Hydraulic conductivity, residue cover and soil surface roughness under different tillage systems in semi- arid conditions. Soil and Tillage Resarch; 85:13-26.

Langdale, G.W., Wilson, R.L. and Bruce, R.R (1990) cropping frequencies to sustain long-term tillage system. Soil Sci. Sol. Am. J. 54: 193 - 198

Langmaach, M.S., Schrader, S., Rapp-Bernhordt, S. and Karin, U.K. (2002). Soil structure rehabilitation. Geoderma, 105:141-152.

Larson, W.E. (1999). Soil Parameters for evaluating tillage needs and operations. Soil and water management and conservation. Soil Science and Society Proceedings, 118-122

Latta, J.O,Garry, J.O, Leary (2003), Long-term comparism of rotation and fallow tillage systems of wheat in Australia. Field Crop Research, 83:173190.

Laurent, C., Zeller, B. Dambrine, E., Francis-ponce, J., Chauvat, M. and Lianque, C. (2004). Origin of the nitrogen assimilated by soil fauna living in decomposing beech litter. Soil Biol. Biochem. 36:1861-1872.

Lavelle, P., Decaens, T., Aubert, M., Barot, S., and Blouin, M. (2006). Soil invertebrates and ecosystem services. Eur. J. Soil. Biol., 42:83-515.

Lhotsky, J. (1991). Komplexni agromeuliracni soustavy prozhutnele pudy. Met Zavad. VYSL VYZK Praxe, Uvtiz Praha, 20. Transaction of the ASAZ 35(5):1347-1354.

Li, L. F., Li, T., and Zhao, Z. W. (2007). Differences of arbuscular mycorrhizal fungi diversity and community between a cultivated land, and old field, and never-cultivated field in a hot and ecosystem of southwest China. Mycorrhiza, 17:655-665.

Licht, M.A. and Al- Kaisi, M. (2005). Strip-tillage effect on seed bed soil temperature and other soil physical properties. Soil and Tillage Research 80:233-249.

Lilienfein, J., Wilcke, W., Vilela, I., Lima, S.D., Thomas, R. and Zech, W. (2000). Effect of no till and conventional tillage systems on the chemical composition of soils solid phase and soil solution of poracilian savannah oxisols. J. Plant Nutr. Soil Sci. 163:411-419.

Limon - Ortega, Augustine, Kenneth D. Zayre, Rhae A. Drijber, and Charles A. Francis (2002), Soil attributes in furrow-irrigated bed planting system in northwest Mexico. Soil and Tillage Research, 63(3-4): $123-132$.

Liu, W., Tollenaar, M., Sternart, T. and Dean, W. (2004) Response of cern grouin yield to spatiod and temporal vonability in emergence. Crop Sci 44: 84. 
Logsdon, S.D., Allmaras, R.R., Wu, L. and Randall, J.B. (1990) Macro porosity and its relation to saturated hydraulic conductivity under different tillage practices. Soil Sci Soc. SM. J. 54:10961101.

Logsdon, S.D., Jordahl, J. and Karlen, D.L. (1993). Tillage and crop effects on ponded and tension in filtration rates. Soil Till. Res. 28(2):179-189.

Lovelock, C.E., Wright, S.F. Clark, D.A. and Ruess, R.W. (2004). Soil stocks of glomalin produced by arbuscular mycrrhiza fungi across a tropical rain forest land scape. J. Ecol. 92:278-287.

Lukosiunas, K (2005). Stubble tillage effects on yield of repeatedly seeded cereals. Research papers of $1 \mathrm{Ag}$ Eng. LUA, Vol.37 (4):5-16 (in luthuamean)

Madari, B., Pechol, L., Macado, D.A. and Torres E. (2005). No-tillage and crop rotation effects on soil aggregation and organic carbon in a Rhodic ferrasil from southern Brazil. Soil Till, Res. 80:1985-2000.

Madejon, E., Moreno, F., Munillo, J.M. and Pelegrin, F. (2007). Soil biochemical response to long term conservation tillage under semi arid mediterranean conditions. Soil Till. Res. 94 (2):346 - 352.

Malhi; S.S. Lemke, R., Wang, Z.H. and Baldev S. Cnhabra(2006). Tillage, ntrogen and crop residue effects on crop yield, nutrient uptake soil quality, and green house gas emissions. Soil and Tillage Research 90 (1-2). 171-183.

Malik, R.K., Ashok, Yadav and Sher Singh (2003) resource conservation technologies in rice wheat cropping system of Indo- Gangetic plainconservation agriculture status and prospects. Httpllwww. Agricasa. Org.

Mapa R.B., Green, R.E. and Santo, L. (1986). Temporal variability of soil hydraulic properties with wetting and drying subsequent to tillage. Soil Sci Soc. Am. J 50:1133-1138.

Marinari, S., Masciandaro, G., Geccanti, B., and S. Grego, S. (2000). Influence of organic and mineral fertilizers on soil biological and physical properties. Bioresource Technology, 72(1): 9-17.

Martinez, E., Functes, J.P., Silva, P., Valle, S., and Acevedo, E., (2008). Soil physical properties and wheat root growth as affected by no tillage and conventional tillage systems in a Mediterranean environment of Chile. Soil Till. Res. 99:232 - 244.

Materechera, S.A. and Mloza Banda, H.R. (1997). Soil penetration resistance, root growth and yield of maize as influenced by tillage on ridges in Malawzi, Soil and Tillage Research (1-21 13-24).

McCarty, G.W., Lyssenko, N.W. and Satrr, J.L, (1998). Short term changes in soil carbon and nitrogen pools during tillage management transition. Soil Soc. AM. J.62:1564-1571.

McDonald, A.J., Riha, S.S., Duxbury, J.M., Steenhvis, T.S., and Laurern, J.G. (2006). Soil physical responses to novel rice cultural practices in the rice- wheat system: Comparative evidence from a swelling soil in Nepal, Soil Till. Res. 36 (2):163175.

McGarry, D., Bridge, B.J. and Radford, B.J. (2000). Contrasting soil physical properties after zero and traditional tillage of an alluvial soil in the semi arid subtropics. Soil Till. Res. 53 (2): 105-115.

McGonigle, T. P., and Miller, M. H. (1991). Winter survival of extra racial hyphae and spores of carbuncular mycorrhizal fungi in the field. Appl. Soil Ecol. 12:41 - 50 .

Mclsaac. G.F., Siemens, J.C., Hummel, J.W. and Tyrrell, A.T. (1994). Economic comparisons of six corn and soybean tillage systems, two soybean spacing on three farm sizes, Appl. Eng. Agric. 6:557-564

McLaughhin and Minease (1995). Managing world soils for food security and environmental quality Advance Agronomy J. Vol. 74:155-192.

McQuaid, B.F. and Olson, G.I. (1998). Soil quality indices of piedmont sites under different management system. Adv. Soil Sci. 21:427-433.

Melero, S. Vanderlinden, K. Ruiz, J.C. and Madejon, E., (2008). Long-term effect on soil biochemical status of a vertisol under conservation tillage system in semi-arid Mediterranean conditions, Eur. J. soil Bio. 44:437 - 442.

Mielke, L.N. and Wilhelm, W.W. (1998). Comparisons of soil physical characteristics in long term tillage winter wheat fallow tillage experiments, Soil and Tillage Res. 49:29-35.

Miller J.J; Kokko, E.E. and Kozub, G.C. (1998) Comparison of porosity in a chernozemic clay loam soil underlong-term conventional tillage and no-till Can J. Soil Sci 78 (4): 619-629.

Mistina, T., and Kovac. K. (1993). Ochranne obrabanic pody vurn, Piestany.

Mitchell, J.P. (2009). Classification of consersation tillage practice in california irrigated row crop systems. University of California division of Agriculture and natural Resources, Publication $8 / 364$

Mohanty, M., Painuli, Misra, A.K., and Ghosh P.K. (2007). Soil quality effect of tillage and residue under rice- wheat cropping on a vertisol in India. Soil and Tillage, 92 (1-2):243-250.

Moncrief, J.F., Wagor, T.L. and Kuzmia, J.J. (1990) Tillage system and cultivation effects on corn growth and yield on well- drained silt loam soil. In A report on field research in soils. Univ. of Minnesota Agric. Exp. Stn.

Moncrief, J.T., Grosland, S.D. and Kuznia, J.J. (1991). Tillage effects on corn growth stand establishment and yield. Isanti County, MN, In A report on field research in soils. Univ. of Minnesota Agric. Exp. Stn.

Monneveux, P., Quillerou, E., Sanchez, C. and Lopezcesati (2006). Effect of zero tillage and residues conservation on continuous mazie cropping in a subtropical environment (mexco). Plant and Soil, 279:95-105. 
Moreno, F., Pelegrin, F., Fernandez, J.E. and Munillo J.M (1997). Soil physical properties, water depletion and crop development under traditional and conservation tillage in southern Spain, Soil Till Res. 41:25-42.

Morison, Jr., J.E., and Chichetser, F.W. (1994). Tillage system effects on soil and plant nutrient distribution or vertisols. J. Prod. Agric. 7:364-372.

Motavalli., P.P, Stevens, W.E. and Harthwig, G. (2003). Penetration of subsoil compaction effect on corn N. availability by deep tillage and application of poultry manure in sandy textured soil. Soil and Tillage Res. 71:121-131.

Mubarak, A.R.; Elsham O.M.E. and Azhan, A.A. (2005). Long and short terms effect of cultivation on properties of a vertisol under sugarcane plantation Soil Tillage Research, 84 (1) :1-6.

Mullen, M., Melhom, C., Tyler, C., and Duck, D., (1998). Biological and biochemical soil properties in on till com. With different cover crops. J. Soil Water Conserve. 5:219-224

Munawar, A., Blevins R.L., Frye, W.W., and Sal, M.R. (1990). Tillage and cover crop management for soil water conversation. Agron. J.82:773-777.

Nafziger, E.D., Carter, P.R. and Graham, E.E. (1991). Response of corn to uneven emergence. Crop Sci. 31:811-815.

Namr, K.I. and Mrabet, R. (2004). Influence of agricultural management on chemical quality of a clay soil of semi-arid Morocco. J. Afr. Earth Sci: 39:485 - 489 .

Nasr, H.M. and Selles, F. (1995). Seedling emergence as influenced by aggregates size, bulk density and penetration resistance of the seed bed. Soil Tillage Research; 34:61 - 76.

NDSU (2008). Soybean planting depth is critical. Htt WW. AG. Udsu.Edu/procrop/syb/sybpoc.osihtm.

Needleman, B.A., Wander, M.M., Bollero, G.A., Boast, G.W., Sims, G.K. and Bullock, D.G. (1999). Interaction of tillage and soil structure: biological active soil organic matter. Soil Sci. Soc. Am. J. 63:1326 - 1334 .

Norwood, D. (1994). Profile water distribution and grain yield as reflected by cropping system and tillage. Agron. J. 86:558 - 563.

Nweke, I. A. (2015a). Effect of landuse on organic matter concentration of aggregate fractions of fallow and cultivated soils. Indian J. Appl. Res. 5(3): 507- 511.

Nweke, I. A., and Nnabude, P. C. (2014a). Aggregate size distribution and stability of aggregate fractions of fallow and cultivated soils. J. Expt. Biol. Agric. Sci. 1(7-special issue): 514-520.

Ogbodo, E. N. ( 2005). Effect of depth of tillage on soil physical conditions, growth and yield of sweet potato in an ultisol at Abakaliki, southeastern Nigeria. Joumal of Agriculture and Social Research, 5: 41-47.

Ohiri, A.C. and Ezumah, H.C. (1990). Tillage effects on cassava (Manihot esculent) production and some soil properties. Soil and Tillage Research 17:221 - 231.

Ohu, J.O. Ekwue, E.L. and Folounso, O.A.(1994).The effect of addition of organic matter on the compaction of a vertisol from northern Nigeria. Soil Technolo. 7(2):155-162.

Ojeniyi, S.O. (1997). Soil and tillage for sustainable agricultural productivity, In: Tillage Reseach and African Agricultureal Development in SubSaharan Africa, K.C Oni (ed.). Proceedings of Nigeria bank of International soil tillage Research organization NCAM,Ilorin, Nigeria.

Okpoku, G., Vyn, T.J. and Shanton, G. J. (1997). Modified no-till system for corn following wheat on clay soils, Agron. J. 85:549 - 556 .

Olaoye, J.O.(2002) Influence of tillage on crop residue cover, soil properties and yield components of cowpea in derived savannah of Nigeria. Soil and Tillage Research 51(1) :161164.

Omidi, H. Tahmasebi, Z., Gorobi, H. and Miransari, M.,(2008). Soil enigmatic activities and available $P$ and $\mathrm{Zn}$ as affected by tillage practices, canla ( Brassica napus L.)cultivors and planting dates. Eur. J. Soil Biol. 44:443-450.

Onwueme, I.C.and Sinha, T.D.( 1991). Soybean. In: Field crop production in tropical Africa, pp.339343. Tropical centre for Agricultural and rural corporation. The Neither lands.

Opara-Nadi, O.A (1990). Tillage practices and their effect on soil productivity in Nigeria. In: organic matter management and tillage in humid and subhumid Africa: pp 87-111. IBSRAM proceedings no. 10, BANGKOK: IBSRAM.

Osunbitan, J.A. Oyedele, D.J. and Adekalu, K.O. (2005). Tillage effects on bulk density. Hydraulic conductivity and strength on a heavy sandy soil in southwestern Nigeria. Soil Till. Res. 82(1):57-64.

Ozpinar, S. and I-ik, A. (2004). Effects of tillage, ridging and row spacing on seedling emergence and yield of cotton. Soil and Tillage Research, 75 (I): 19-26.

Ozpinar, S.and Cay, A. (2005). Effects of minimum and conventional tillage systems on soil properties and yield of winter wheat ( Triticum a estivum L.) in clay-Loam in the Canakkale region. Turk. J. Agric. For. 29 (1):9-19.

Pagliai, M., Paghone, M., Pannin, T., Maletta, M. and Hamarca, M.(1995). The structure of two alluvial soils in Haly after 10 years of conventional Land Minimum Tillage. Soil Tillage Resarch, 34:209223.

Panayiotopoulos, K.P., Padadoptulous, C.P., and Haffiloannidou, A. (1994). Compaction and penetration resistance of an Alfisol and Entisol in USA Soil taxonomy and their influence on root growth of maize seedlings. Soil and Tillage Resarch, 31:323-337.

Parr. J.F., Papendick, R.I., Hornick, S.B. and Mayer, R.E. (1990). The use of cover crops, mulches and 
tillage for soil water conservation and weed control. In organic matter management and tillage in humid and sub-humid Africa. Pp246-261 IBSRAM Proceedings No.10 Bangkok: IBSRAM.

Paul, E.A., Follett, R.F., Leavitt, S.W., Halvorson, A. Peterson, G.A. and Lyon, D.I. (1997). Radio carbon dating for determination of soil organic matter pool sizes and dynamics. Soil Sci. Soc. Am. J. 61:1058-1067.

Paustian, K., Collins, H.P. and Paul, E.A. (1997). Management controls on soil carbon, P.15-49:In: E.A. Paul (ed), Soil organic matter in temperate agro ecosystems, CRC. Press, Boca Rton, FL.

Pettigrew Willian T and Michael A. Jones (2001) Cotton growth under no-till production in the lower Mississippi river valley alluvial flood plain, Agronomy Journal, 93:1398-1404.

Pierce, F.J., Fortin, M.C. and Station, M.J. (1994). Periodic ploughing effects on soil properties in notill. farming system. Soil Sci. Am. J. 58(6): 1782 1787.

Pieterse, C .M .J., Van Wees, S. C. M., Holl land, E. Van Elt, J. A. and Van Loon, L.C. (1996). Stematic resistence in arabidopsis induced by biocontrol bacteria is independent of salicyclic acid accumulation and pathogensis -Related gene expression. Plant Cess. 8:125 -1237.

Pikul, J.L., Jr., Chilom, G., Rice, J., Eynard, A., Schumacher, T. E., Nichols, K., Johnson, J.M.F., wright, S., Caesar, T., and Elisbury, M. (2009). Organic matter and water stability of field aggregates affected by tillage in south Dakota, Soil Sci. Soc. Am. J.73:197-206.

Pillai, U.P. and Mc Garry, D. (1999). Structure repair of a compacted Vertisol with wet-dry cycles and crops. Soil Sci.Soc. Am. J.63:201-210.

Pirmoradian, N. Sepaskhah, A.R., and Hajabbasi M.S. (2005). Application of fractal theory to quality soil aggregate stability as influenced by tillage treatments. Biosyst. Eng. 90(2): $227-234$.

Pommel, B. Mouraux,D., Cappellen, O., and Ledent J.F.,(2002). Influence of delayed emergence and canopy skips on the growth and development of maize plants: a plant scale approach with CERESMaize. Eur.J. Agron 16:263-277.

Popp, M.J., Keisling, T.C., Dillon, C.R. and Manning P.M. (2002). Economic and Agronomy Assessment of deep Tillage in Soybean production on Mississippi river valley soils. Agronomy Journal 39:164-169.

Poss, R., Smith, C.J., Dunin, F.X. and Angus, J.F. (1995). Rate of soil acidification under wheat in a semi-arid environment. Plant soil 177:85-100.

Prihar, S.S., Gajiri, P.R. and Cheema, H.S. (2000) Migration and Tillage effects on root development, water use and yield of wheat, on coarse textured soils. Journal of environmental issues and agriculture in developing countries Vol.1 No1/2 Imigration Science, 12:161-168.
Puget, P., Chenu, C.; and Balesdent, J. (2000). Dynamics of soil organic matter associated with particle-size fractions of water-stable aggregates. Eur. J. soil Sci. 51:595 - 605.

Pulatov Alim (2002). Results of zero tillage in wheat production in Uzbekistan, International workshop on conservation agriculture for sustainable wheat production in rotation with cotton in water resource areas, 14-18 october, 2002 Tashkent, Uzbekistan.

Raper, R.L., Reeves, D.W., Burmester, C.H. and schwab, E.B.(2000). Tillage depth, tillage timing and cover crop effects on cotton yield, soil strength, and tillage energy requirements Appl. Eng. Agric. 16(4) : 379 -385.

Rashidi, M. and Keshararzpour, F. (2008). Effect of different tillage methods on soil physics properties and crop yield of melon (cucumismelo). AmericanEurasian J. Agric. Environ. Sci. 3:31-36.

Rashidi, M. and Khabbaz, B.G. (2009). Responses of crop yield and yield components of tomato to different tillage methods in the arid lands of varamin, Iran. Biennial conference of the Australian society for Engineering in Agriculture (SEAg). September 13-16, Brisbane, QLD, Australia.

Rashidi, M. Keshavazpour, F. and Gholami, M. (2008). Effect of different tillage methods on yield and yield components of forage corn. American - Eurasian J. Agric. Environ. Sci. 3:347 - 357.

Rawson, M.H. and Macpherson, H.G. ( 2000). Irrigated wheat, FAO, Rome, Italy.

Raymond, W.M. and Roy, L.D. (1992). Organic matter. An introduction to soil and plant growth, 6th edn and container media (Delhi: prentice Hall). Appl. 181-224.

Reddy, S.S. Reddy, K.C. Tiffany, R. (2007). Influence of tillage and poultry litter application on carbon dioxide efflux and carbon storage in soil under cotton production system. Proceedings of ASACSSA-SSSA 2007. International meetings, New Orleans, L.A. Nov 4-8 2007.

Reicosky, D.C. Kemper, W.D. langdale, G.W. Douglas C.L.Jr. and Rasmussen, P.E. (1995). Soil organic matter changes resulting from tillage and biomoss production. Jounal of Soil and Water Conservation 50: 253-262.

Rhoton, F. E. (2000). Influence of time on soil response to no- till practices. Soil, Sci. Soc. Am.J.64:700-709.

Richard, G.J. Boiffin, J.and Duval, Y. (1995). Direct Drilling of sugar beat (Beta villgaris $L$ ) into a cover crop: Effects on soil physical conditions and crop establishment. Soil and Tillage Res. 34:169-185.

Rillig, M.C. (2004). Arbusclar mycorrrhiza, glomalin, and soil aggregation Can J. Soil Sci. 84:355-363

Roldan, A., Salina-Garcia, J.R., Alguacil, M.M., and Caravaca, F. (2005). Changes in soil enzyme activities., fertility, aggregation and C. sequestration meditated conservation tillage 
practices and water regime in a maize field. Appl. Soil Ecol. 30:11-20.

Romaneckas, K. Romaneckiene, R. and sarauskis, E. (2006). The effect of primary soil tillage methods on sugar beat growth on light loam luvisol. Zemdirbyste /Agriculture, 93:81-87.

Roseberg, R. L. and McCoy, E.L. (1992). Tillage and traffic induced changes in macroporosity and macropore continuity: Air permeability assessment. Soil Sci Soc. Am.J. 56: 1261-1267.

Rovira, P. and Vallejo, V. R. (2002). Labile and recalcitrant pools at different depths in soil: An hydrolysis approach. Geoderma 107:109-141.

Rowland, K. R. J. (1993). Dry land farming in Africa. C.T.A, The Haque, Netherlands, 249 PP.

Rydberg, T (1990). Effect of ploughless tillage and straw incorporation on evapouration. Soil and Tillage Research, volume 17: 303-314.

Santini, A., Romano, N., Ciollaro, G.and comegna, V. (1995). Evaluation of a laboratory inverse method for determining unsaturated hydraulic properties of a soil under different tillage practices. Soil Sci.160(5):340-351.

Sarauskis, E. and Romanckas, K. (2002). Comparative research of sugar beet sowing into stubble and into ploughed and cultivated soil. Agriculture Eng. Research papers of Lithuanian institute of Agricultural Eng. Lithuanian University of Agriculture 34(2):33-42(in Lithuanian).

Sarkar, S., Paramanick, M. and Goswani, S. B. (2007). Soil temperature, water use and yield of yellow sarson (Brassica napusl var glauca) in relation to tillage intensityand mulch management under rainfed low land ecosystem in eastern India. Soil and Tillage Res. 93(1). 94-101.

Sayre Kenneth, D. (2006). Raised bed cultivation Encyclopaedia of soil science.

Sayre, K. d. and Hobbs, P., (2006). The raised-bed system of cultivation for irrigated production conditions. In: sustainable agriculture and the rice - wheat system, Lal. R., Hobbs, P., Uphoff, N. and Hansen, D. O (eds). Ohio State University Columbia, Ohio USA, pp $337-355$.

Schlesinger, W.H. (1997). Biogeochemistry: An analysis of global change P.558 Academic press New York.

Scow, K.M., Somasco, O. Gunapala, N., Lau, SD., Venette, R., Ferris, H., Miller, R. and Shennan, C. (1994). Transition from conventional to low input agriculture changes in soil fertility and biology. California Agriculture, 48(5): 20-25.

Shah, S.A., Shah, S.M., Mohammad, W., Shafi, M., and Nawaz, H., (2009). N uptake and yield of wheat as influenced by integrated use of organic and mineral nitrogen. Int. J. Plant Prod. 3:45-56.

Shakin, H.S. and Dindal, L.D.(1997). Density and biomass of earthworms in forest and herbaceous microecosystems in central New York, North America. Soil Biol Biochem. 29:275-285.
Sharma, A.K, Pillar-McGarry, U. and McGarry .D ( 1996) Repair of the structure of a compacted vertisol- via wet dry cycles, Soil Tillage Res. 38:17-33.

Sherrod L.A, Peterson, G.A. West fall, D.G. and Ahuja, L.R.(2003). Cropping intensity enhances, soil organic carbon and nitrogen in a no-till agro eco system. Soil Sci. Soc. Am. J. 67:1533-1543.

Shipitalo, M.J. Dick, W.A. and Edwards, W.M. (2000) Conservation tillage and macro pore factors that affect water movement and the fate of chemicals. Soil Tillage Research,53:167-183.

Sial, R.A. Chuadhary, E.H. Hussain, S. and Naveed, M. (2007). Effect of organic manures and chemical fertilizers on grain yield of maize in rain fed area, Soil and Environment, 26(2):130-133.

Sidhu, Dilrajand Sjoerd W Diuker (2006) soil compaction in conservation tillage crop impacts. Agronomy Journal 98:1257-1264.

Sidiras, N. and Kendris-takis, E.(1997). Effect of two planting system on soil strucyure and root growth of maize (Zea Mays L.), J. Agron. Crop Sci., 178:147-149.

Sieverding, Er. (1991). Vesicular Arbuscular mycorrhiza management in tropical agroecosystem. Deutshe Gesellschaft. Technische Zusammeharbeit (GTZ) GMBH, Eschborn:371p

Sikora, L.J., Yakovchenko, V. and Kaufman, D. D. (1995). A proposed soil quality indicators. In: Cook, A.F., Lee, H.C. (eds). Soil management in sustainable Agriculture WyeCollege press, 321318.

Sinah Surendra, Sherma, S. N. and Rajendra Prasad (2001). The effect of seeding and tillage methods on productivity of rice-wheat cropping system. Soil and Tillage Research 61:125-131.

Singer, M.J. and Mums, D.N. (1999). Soils: An introduction 4th edn. Macmillan Pub. Co. Upper Saddle River, NJ, USA.

Six, J. Paustian, K. Elliott, E.T. and Combrink, C. (2000). Soil structure and soil organic matter. 1. Distribution of aggregate size classes and aggregate associated carbon. Soil Sci. Soc. Am.J.64:681-689.

Six, J., Elliot, E.T., and Paustian, K. (1999). Aggregates and soil organic matter dynamics under conventional and no-tillage systems Soil Sci. Sci. Am. J.63:1350-1358.

Six, J., Elliot, E.T., Paustain, K. and Doran, J.W. (1998). Aggregation and soil organic matter accumulation in cultivated and native grass land soils. Soil Sci. Soc. Am J. 612:1367- 1377.

Six, J., Merckx, R., Kimpe, K., Paustion, K. and Elliot, E.T. (2006). A revaluation of the enriched labile soil organic matter fraction Eur. J. Soil Sci. 51:283-293.

Smith J. L. and Doran, J.W. (1996). Management and use of $\mathrm{pH}$ and electrical conduction of soil quality analysis Pp169 - 187. In J.W. Doran and Jones, 
A. J. (eds). Methods of Assessing soil quality, SSSA special publ. 499, SSA, Madison, W.T.

Smith, S.E., Facelli, E., Pope, S. and Smith, F.A. (2010). Plant performance in stressful environment,: Interpreting new and established knowledge of the roles of arbuscular mycorrhizas. Plant and Soil. 326:3-20.

Somaratine, N.M. and Smetten, K.R.L. (1993). Effect of cultivation and rain drop impact on the surface hydraulic properties of an Alfisol under wheat Soil Tillage Research, 26(2):115-125.

Sparrrow, L.A. Cotching, W.E. Cooper, J. and Rowley, W. (1999). Attributes of Tasmanian ferrsols under different agricultural management. Aust. J. soil. Res. 37(4): 603-622.

Stamatiadis, S., Wemer, M. and Buchanan, M. (1997). Field assessment of soil quality as affected by composed fertilizer application in broccoh field. Appl. Soil Ecol.12(13):217-225.

Stancevicius, A. Jodaugiene, D. Spokiene, N. Raudorius, S. and Treciokas, K. (2003). The influence of long term ploughing and ploughless soil tillage on soil properties and spring barley crop. Agriculture scientific Articles of LIA, Vol. 83(3):40-51(in Lithuanian).

Starr, L.L. (1990). Spatial and temporal variation of ponded infiltration. Soil Sci. Soc. Am. J. 54:629636.

Stewart, G.A. and Vyn, T.J. ( 1994). Influence of luhaxle loads and tillage systems on soil properties, Soil Tillage Research, 29 (2-3): 229235.

Stoskopf, Neal. C. (1981). Understanding crop production. Reston publishing company. Inc., Reston Virginia. A prentice - Hall Company.

Stroppel, A. (1997). Soil tillage machine of the futures. Proc. 25 Int'l Symp. actual task on Agriculture Engineering, Opatija. 125-128.

Strudley M.W., Green, T.R. and Ascough, J.C. (2008). Tillage effects on soil. Soil Till. Res. 99:4-98.

Talukadar, A.S.M.H.M., Craig Meisner, M.J. Kabir, A.B.S. Hossain and M. Harunur-Rshid. (2004). Productivity of multi-crops sown on permanent raised beds in the tropics Brisbane Queensland, Australia, 4th International Crop Science Congress.

Temesgen, M. (2007). Conservation tillage systems and water productivity implications for small holder farmers in semi-arid Ethiopia, Ph.D Thesis Taylor and Francis/Balkena, Leiden, IreNetherlands.

Tessier, S., Peru, M. Dyck, F.B., Zenter, R.P. and Campbell, C.A. (1990). Conservation tillage for spring wheat production in semi-arid Saskatchewan. Soil Tillage Research, 18:73 - 89.

Thorburn, P.I. (1992). Structural and hydraulic changes in a vertosoil under different fallow management techniques. Soil Tillage Res. 23:341 -359 .

Tisdall, J.M. (1996). Formalition of soil aggregates and accumulation of soil organic matter, Pp 57 -
96. In: M.R. Carter and B.A. Stewart (eds) Structure and Organic Matter Storage in Agricultural Soils. CRC Press Lewis Publishers, Boca Raton, FI.

Treseder, K.K. and Turner, K.M. (2007). Glomalin in ecosystems. Soil Sci. Am. J. 71:1257 - 1266.

Tripathi, R.P., Peepyush Sharma and Surendra Singh. (2007). Influence of tillage and crop residues on soil physical properties and yields of rice and wheat under shallow water table. Soil and Tillage Research, 91(1-2):221-226.

Troeh, F.R. Hobbs, J.A. and Donahue, R.L. eds. (2004). Soil and water conservation for productivity and environmental protection, 4th ed. Prentice Hall, N.J.

Trojan, M.D. and Linden, D.R. (1998). Macroporosity and hydraulic properties of earthworm-affected soils as influenced by tillage and residue management, Soil Sci. Soc. Am. J. 62:1687 1692.

Truu, M., Truu, J. and Ivask, M. (2008). Soil microbological and biochemical properties for assessing the effects of agricultural management practice in Estonian cultivated soils. Eur. J. Soil Biol. 44:231 - 237.

Turapov, I.T., Avezor, R.R. and Kasimov, B.K.H. (1987). Teplovoy i radiatsronniy rejimi grebnevoy $\mathrm{i}$ rovnoy pochvi. Fan Tashkent (in Russian).

Unger, P.W. (1990). Tillage and residue management in rain fed agriculture: present and future trends, In: Organic-matter management and tillage in IBSRAM proceedings No.10. Bangkok: IBSRAM.

Unger, P.W., Stewart, B.A., Parr, J.F., and Singh, R.P. (1991). Crop residue management and tillage methods for conserving soil and water in semiarid regions. Soil and Tillage Research 20:219240.

Unger, W.P.(1992). Infiltration of stimulate rainfall tillage system and residue effects. Soil. Sci. Soc. Am. J.56:283-289.

Uri, U.D. (1999). The economic benefits and costs of conservation Tillage. Journal of sustainable Agriculture 15:5-26.

Van Es, H.M., Ogden, C.B., Hill, R.L., Schindelbeck, R.R., and Tsegaye, T. (1999). Integrated assessment of space, time and managementrelated variability of soil hydraulic properties. Soil Sci. Soc. Am. J. 63:1599-1608.

Van Landen, G.W.J.(2000). Soil degradation in central and Eastern Europe. ISRIC report (2000/5)P 15

Van Oost, K., Govers, E., Van Muysen, W.; and Quine, T.A. (2002). Modeling translocation and dispersion of soil constituent by tillage on sloping land. Soil Sci. Soc. Am. J. 64(5): 1733 - 1739

Vanden Bygaat, A.J.; Protz, R. and Tomlin, A.D. (1991). Changes in pure structure in a no-till chromosequence of silt loam soils, southern Ontario. Can. J. Soil Sci., 79:149 - 160.

Varsa, E. C., Chong, S.K., Abolaji, J.O., Faraguhar D.A. and Olsen, F.J. (1997). Effect of deep tillage 
on soil physical characteristics and corn (zea may L.) root growth and production. Soil Tillage Research, 43:219 - 228.

VerVoort, R.W., Dabney, S.M. and Romkens, M.J.M. Romkens,(2001). Tillage and row position effects on water infiltration characteeeristics. Soil Sci. Soc. Am. J.65: 1234.

Wander Mim, S. J. Traina, Stinner, B.R. and Peters S.E. (1994). Organic and conventional management effects on biological active soil organic matter pools. Soil Sci. Soc. Am (J. 588:1130 - 1139

Warkentin, B.P.(1995). The changing concept of soil quality. Journal of Soil and Water Conservation 50:226-236.

Weber, J. (1990). Long-term conventional and notillage effects on selected sil physical properties. Soil. Sci. soc. Am. J., 54:80 - 85

West, T.O. and Post, W. (2002). Soil organic carbon sequestration rates by tillage and crop rotation a global data analysis. Soil Sci. Soc. Am. J 66:193 1946.

Wezel, A, Rajot, J.L and Herbring, C. (2000). Influence of strubs on soil characteristics and their function in sahelian agro-ecosystem in semi-arid Niger. Journal of AridEnvt 44:383 - 398.

Wilson, T. C., Paul, E. A., and Harwood, R.R. (2000). Biologically achieved organic matter fractions on sustainable cropping systems. Appl. Soil Ecol. 16(1): $63-76$.

Wright, S. F., Green, V.S., and Cavigelli, M. A. (2007) Glomalin in aggregate size classes from three different farming systems. Soil Till. Res. 94:546 549.

Wright, S. F., Starr, J.L. and Paltineanu, I.C (1999). Changes in aggregates stability and concentration of glomalin during tillage management transition, Soil Sci. Soc. Am. J. 63:1825 - 1829.

Wright, S.F. and Upadhyaya, A.m (1998). A survey of soils for aggregate stability and glomalin, a glycoprotein produced by hyphae of arbuscular mycorrhizal fungi, Plant Soil 198:97 - 107.

Wu, L. Swan, J.B., Paulson, W.H. and Randall, G.W. (1992) Tillage effects on measured soil hydraulic properties. Soil. Tillage Research, 25:17 - 33.

Yang, X., Chen, C., Luo, Q., li, L., and Yu, Q., (2011). Climate change effects on wheat yield and water use in Oasis crop land. Int. J. Plant Prod. 5: 8394.

Zhang, H.O., Horge, H.R.and Ringe, H. (1997). Effectiveness of organic matter in corporation in reducing soil compatibility. Soil Sci. Soc. Am. J. 61(1):239-245

Zhu, Y.G. and Miller, R.W. (2003). Cabon cycle by arbuscular mycorrhizalfungi in soil plant systems. Trends Plant Sci. 8:407-409. 